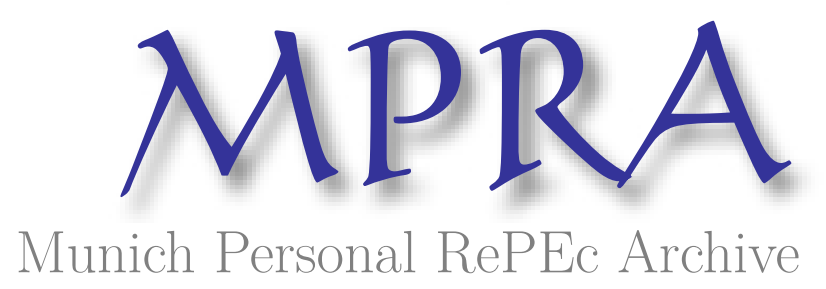

\title{
The dangerous rise of economic interventionism
}

Zimmermann, Thomas A.

ASERI (Alta Scuola di Economia e Relazioni Internazionali), Università Cattolica del Sacro Cuore, Milano (Italia)

20 January 2010

Online at https://mpra.ub.uni-muenchen.de/37262/

MPRA Paper No. 37262, posted 10 Mar 2012 15:01 UTC 


\section{RELAZIONI INTERNAZIONALI E SCIENZA POLITICA}

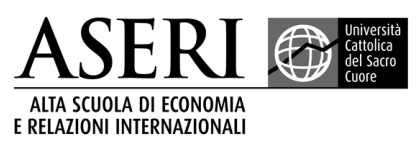

Collana diretta da Vittorio Emanuele Parsi

44 

SIMONA BERETTA

ROBERTO ZOBOLI (eds.)

Crisis and Change

The Geopolitics

of Global Governance

L.P vitae pensiero 
The Postgraduate School of Economics and International Relations (ASERI) is an education and research center of the Università Cattolica, created to study the great economic and political transformations of a globalised world. Director: prof. Lorenzo Ornaghi. More information on aseri.unicatt.it

This book has been made possible thanks to a collaboration between Regione Lombardia and Università Cattolica, aimed at increasing the exchanges of international researchers and human capital.

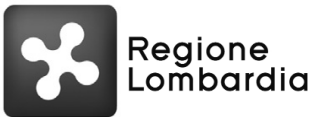

www.vitaepensiero.it

Le fotocopie per uso personale del lettore possono essere effettuate nei limiti del $15 \%$ di ciascun volume dietro pagamento alla SIAE del compenso previsto dall'art. 68, commi 4 e 5, della legge 22 aprile 1941 n. 633.

Le fotocopie effettuate per finalità di carattere professionale, economico o commerciale o comunque per uso diverso da quello personale possono essere effettuate a seguito di specifica autorizzazione rilasciata da CLEARedi, Centro Licenze e Autorizzazioni per le Riproduzioni Editoriali, Corso di Porta Romana 108, 20122 Milano, e-mail: autorizzazioni@clearedi.org e sito web www.clearedi.org

(C) 2012 Vita e Pensiero - Largo A. Gemelli, 1 - 20123 Milano ISBN 978-88-343-2131-7 


\section{The Dangerous Rise of Economic Interventionism}

\section{Introduction: Economic crises and interventionism ${ }^{1}$}

\subsection{The attractions of economic interventionism}

Economically hard times such as the 2007-2009 financial and economic crisis tend to place policymakers under stress. In the light of shrinking demand and the pains inflicted by structural adjustment on economies and their populations, calls for increased protection and government intervention abound. Policymakers come under strong pressure to respond positively to such calls, particularly when voiced by well-organised interest groups with political power, if they wish to maximise political support.

Economic crises therefore almost inevitably lead to an increasing degree of government interventionism in the economy. Its primary goal is usually the prevention of rising unemployment.

One key ingredient is classical protectionism through trade and investment policy measures (such as tariffs or various non-tariff barriers to trade), affecting trade in goods, services, and cross-border investment flows. Their key purpose is to keep demand and capital at home.

\footnotetext{
${ }^{1}$ Thomas A. Zimmermann (http://www.zimmermann-thomas.ch) is a research associate at the Swiss Institute for International Economics and Applied Economic Research (SIAW-HSG) at the University of St. Gallen, Switzerland, He serves as head of the division «Law, Organisation and Accreditation» and member of the board at the Swiss State Secretariat for Economic Affairs (SECO) in Berne, Switzerland. The author has prepared this paper exclusively in his personal capacity as a researcher. All the views expressed in this paper are exclusively those of the author and shall not be attributed to any institution to which the author is affiliated. This version of the paper reflects developments until 20 January 2010. The author gratefully acknowledges valuable comments from Heinz Hauser and Christoph A. Schaltegger, as well as dedicated editorial assistance from Pamela Gasser-Johnson. The remaining errors are solely those of the author.
} 
Another key element of economic interventionism is fiscal policy - through specifically designed stimulus programmes, increased subsidisation, government credits, and emergency actions (including outright firm ownership) with a view to supporting firms or bailing out entire industries (e.g. banks, car manufacturers). These expansionary fiscal policies are meant to complement the effects of automatic stabilisers. The latter regularly include unemployment and other social insurances, as well as the cycle-smoothing effects of the tax system. The purpose of fiscal policy measures is to bridge a temporary dip in demand and to prevent otherwise healthy firms from closing and staff layoffs from rising. With a view to the emergency measures taken in the banking sector, their purpose is also to prevent domino effects and the destabilisation of the financial sector in the event that large or interconnected institutions of systemic importance should fail (e.g. the collapse of the American investment bank LEHMAN BROTHERS).

Monetary policies may also be altered in response to crises. The primary instrument is a reduction of interest rates by central banks. In the current crisis, several central banks have taken additional measures, commonly summarised as 'unconventional policies' or 'quantitative easing', including inter alia purchases of bonds or other securities by the central bank. These measures have been taken with a view to increasing the money supply and unfreezing credit markets after the possibilities of cutting interest rates have been exhausted. Finally, purchases of foreign currencies by central banks can be used in order to suppress the value of the domestic currency, as a means of increasing the supply of the domestic currency with a view to fighting deflation and, possibly, to giving an edge to a country's exporters.

At the time of writing (December 2009), we may conclude that economic interventionism has served its purpose relatively well: political stress, turmoil and instability have been prevented in most countries for the time being, as governments have largely remained in power; most major economies are currently coming out of the recession or appear, at least, to have bottomed out; asset markets have rebounded (in particular the stock market) and banks are seemingly on their way towards consolidation of their balances; the rise of unemployment has been more moderate than had been feared, at least in some countries; resource prices are rising again and the risk of the world economy falling into a 1930s style deflationary spiral also appears to have been banned as of now. 


\subsection{The dangers of economic interventionism}

Despite its attractions and achievements in the short term, economic interventionism may nevertheless come at a heavy cost in the longer term - a cost which potentially surmounts the benefits of its short-term blessings.

On the micro-economic level, protectionist measures distort production, consumption and factor allocation, thereby creating economic inefficiencies and weighing heavily on wealth creation, prosperity and growth perspectives. Increased subsidisation and government involvement in business ownership or the credit industry bear the risk of creating or maintaining over-capacities. More generally, political mismanagement and state failure (as opposed to the market failure which is often cited as a pretext for interventions) may result from such actions. State interventions may also lead to moral hazard: For example, lax monetary policies in conjunction with bailout perspectives for financial institutions create strong incentives for excessive risk-taking in the financial sector.

On the macro-economic level, interventionism may destabilise an economy in the longer run and undermine its sustainability. Expansionary fiscal policies such as stimulus programmes, bailouts and emergency measures often imply massive deficits and a build-up of excessive debt, weighing heavily on future generations. They provoke increased taxation during the payback period (further impairing productivity), doubts about the government's solvency and sovereign default risks, the crowding-out of private borrowing, and/or increasing long-term interest rates. They also imply a risk of future inflation if price stability were to be sacrificed for the benefit of a seemingly 'easy way' out of debt.

Monetary policy interventions in the form of overly lax policies may lead to new asset price bubbles - particularly in cases where credit channels are clogged and excess liquidity flows into asset markets. This, in turn, may result in subsequent crises, making lax monetary policies a root cause of a vicious circle of boom-and-bust, and in the exorbitant economic and social cost which each bursting bubble entails. Moreover, where easy monetary policies are not phased-out in due time, inflation may loom. In combination, heavy fiscal and monetary interventions may have a profound impact on currencies, possibly leading to international monetary disorder and thereby provoking further interventions such as capital controls or other protectionist responses.

Beyond its economic costs, interventionism also bears political costs: It creates vested interests that will seek to increase their influence on policy-making and to cement the state interventions from which they 
benefit beyond the crisis. The share of directly unproductive, rentseeking activities in the economy may therefore increase, reducing the headroom for governments to undo the interventions in due time. Furthermore, institutional balances may be disturbed, e.g. if Central Banks come under pressure not to withdraw unsustainably lax monetary policies to which the economy has become used. If macro-economic conditions deteriorate up to the point where a state default and/or high inflation lure, the result may be a breakdown of public services and public order, undermining democracy and political stability. And on the international level, the recourse to measures of nationally oriented economic interventionism is a potential source of tensions and conflicts.

Finally, there are also more fundamental, societal and psychological costs of economic interventionism. Government interventions of all sorts restrict the freedom of transaction of individuals and economic freedom more generally, thus undermining a key pillar of any free and democratic society. Deficit-spending by states provides a poor role model for individual economic actors. Similarly, lax monetary policies punish savers and reward profligacy, overconsumption, indebtedness, leverage and hazardous risk-taking. Where such policies lead to high inflation, the negative economic and psychological effects on the economy and society at large are exacerbated, in addition to the inherent violation of the right to private property which is a key foundation of any free society.

Moreover, the moral hazard emanating from bailouts through the privatisation of profits and the parallel socialisation of losses leads to a separation of the risk to lose and the chance to make profits, thus undermining the basic sense of responsibility that is needed for the long-term success of any economy. It may drive a country's most productive forces and most brilliant brains into activities of questionable value, where money can be made easily, possibly at the expense of the public. At the same time, it leaves the rest of the economy with a sense of frustration and injustice, thus shaking the public support for the market economy in a dangerous way.

Another fundamental problem of economic interventionism is that an increased share of government in the economy - through both higher expenditure and higher taxation - increases the dependence of ever growing parts of the population on redistribution activities of the states. It thus alienates people further from the productive mechanisms of wealth creation. 


\subsection{Purpose of the paper}

In summary, economic interventionism may well serve the purpose of providing temporary relief to affected economies and to alleviate stress on policymakers. However, the manifold costs of economic interventionism may easily surmount its benefits in the medium to long term. It is therefore of paramount importance that policymakers exercise restraint in taking interventions; that such interventions are carefully chosen with a view to minimising their negative side effects; and that such measures are quickly withdrawn once the worst of a crisis is over. In light of the characteristics of the political market and the institutional inertia, and as experience with previous crises shows, there is a real risk that provisional interventions become permanent or that the exit occurs too late. If they do so, they keep a hypertrophic economy going with all the economic, political and other costs detailed above.

The purpose of this paper is twofold: one objective is to explore whether, how, and to which extent policymakers have resorted to policies of economic interventionism in reaction to the 2007-2009 financial and economic crisis. The second objective is to summarise policy options of an exit from these various interventions and of a return to more market-oriented mechanisms in the world economy.

In the absence of a widely-used and clear definition of the term 'economic interventionism' we understand it rather broadly: The underlying concept is i.) the preference for supporting a country's own firms, industries, workers, capital owners as well as for keeping jobs, capital, economic activity, and tax revenue within the country; and ii.) the desire by political leaders to exercise political control over the economic cycle. The implementation of this concept occurs through government intervention in the economy at two levels: i.) restrictions of the freedom of transaction of individuals by treating international economic transactions less favourably than national transactions (protectionism); and ii.) fiscal and monetary policy interventions with a view to controlling the business cycle, usually by increasing demand and by re-inflating prices, thereby influencing decisions of consumption, production and factor allocation. Both trajectories of economic interventionism imply increased influence of the state over private economic actors and, therefore, a shift of power.

In accordance with this approach, we seek to analyse a wide spectrum of measures in various sectors. This paper covers trade policy in goods and services (chapter 2), investment policies (chapter 3), fiscal policies (chapter 4), and monetary policies (chapter 5 ). In doing so, this essay aims at drawing the 'big picture'. We are aware that the creation 
of a complete list or a detailed analysis of the measures taken by governments around the globe would be beyond the reach of this paper - first on account of the sheer number of measures taken, and second on account of the dynamism with which developments in this area take place. We therefore include several references to recent publications and databases in which the individual policy measures are catalogued or discussed in more detail ${ }^{2}$. Chapter 6 offers a summary of the main findings, whereas chapter 7 discusses policy options for an exit from these interventions.

\section{Trade policies}

2.1. Overall assessment: The broken promise to refrain from protectionism

International trade has been severely affected by the crisis: As per August 2009, global trade was down 18\% from its peak in April 2008, and down $15 \%$ year-on-year. As the world economy has improved in the $2^{\text {nd }}$ half of 2009, trade has been increasing since, but flows are still far away from their pre-crisis levels ${ }^{3}$.

In the Declaration issued at their summit on 15 November 2008, the G-20 Governments declared: «We underscore the critical importance of rejecting protectionism and not turning inward in times of financial uncertainty». This and similar pledges have since been reiterated with some frequency. At the last G-20 summit in Pittsburgh on 24 and 25 September 2009, the 'Leader's statement' reads «We will fight protectionism. We are committed to bringing the Doha Round to a successful conclusion in 2010», as well as «We will keep markets open and free and reaffirm the commitments made in Washington and London: to refrain from raising barriers or imposing new barriers to investment or to trade in goods and services, imposing new export restrictions or implementing World Trade Organization (WTO) inconsistent meas-

\footnotetext{
${ }^{2}$ See the references in the bibliography at the end of this paper, in particular the publications by the WTO, the OECD, UNCTAD, the IMF, and Global Trade Alert.

${ }^{3}$ For more detailed figures, see World Trade Organisation (WTO) (ed.), Overview of Developments in the International Trading Environment, WTO, Document No. WT/ TPR/OV/12, Geneva 18 November 2009. Available at http://docsonline.wto.org/ DDFDocuments/t/WT/TPR/OV12-00.doc., Part A, Page A-8ff.
} 
ures to stimulate exports and commit to rectify such measures as they arise $»^{4}$. Have countries lived up to these reiterated pledges?

The measures taken by countries in the area of trade policy have since been monitored, inter alia, by 'Global Trade Alert' (GTA) - an independent initiative co-ordinated by the Centre for Economic Policy Research (CEPR) and managed by Simon EvenETt at the Swiss Institute for International Economics and Applied Economic Research at the University of St. Gallen (SIAW-HSG) ${ }^{5}$. GTA runs a publicly accessible database $^{6}$ and has, since its inception in June 2009, published three major reports 7 . As EvenetT holds in his recent analyses, the G-20 pledges and exhortations to eschew protectionism have been subject to a 'serial violation', and a 'protectionist juggernaut' is under way'.

According to the $3^{\text {rd }}$ GTA Report of December 2009, governments around the globe have introduced 297 beggar-thy-neighbour policy measures since the G-20 summit of November 2008, i.e. more than one measure per working day. Another 56 measures implemented are likely to have harmed foreign trade interests, bringing the total to 353 measures. Regarding all trade policy measures taken since that summit, the number of protectionist trade measures is nearly six times the number of benign or liberalising measures. At the same time, the report finds that there are a further 188 state measures announced in the pipeline which, if implemented, would likely harm foreign commercial interests ${ }^{10}$.

A monitoring report by the WTO of July 2009 is less pessimistic, but still holds that «the number of new trade-restricting or distorting measures announced or implemented since 1 March 2009 exceeds the number of new trade-liberalizing or facilitating measures by a factor of more than two». According to the same report, «this compares unfavourably with the general situation prevailing over the past few years

\footnotetext{
${ }^{4}$ See http:/ / www.pittsburghsummit.gov/mediacenter/129639.htm.

${ }^{5}$ For more information on Global Trade Alert, please revert to http:/ / www.globaltradealert.org/about.

${ }^{6}$ See http:/ / www.globaltradealert.org.

${ }^{7}$ S. Evenett (ed.), Broken Promises - A G-20 Summit Report by Global Trade Alert [2 ${ }^{\text {nd }}$ GTA report], Global Trade Alert / Centre for Economic Policy Research (CEPR), London 2009; S. Evenett (ed.), Global Trade Alert $1^{\text {st }}$ Report, 8 July 2009, Global Trade Alert / Centre for Economic Policy Research (CEPR), London 2009; and EvenETt (ed.), The Unrelenting Pressure of Protectionism - The $3^{\text {rd }}$ GTA Report $-A$ Focus on the Asia-Pacific Region, Global Trade Alert / Centre for Economic Policy Research (CEPR), London December 2009.

${ }^{8}$ See Evenett, Broken Promises, p. 3.

${ }^{9}$ See Evenett, Broken Promises, p. 2; Evenet, The Unrelenting Pressure, p. 3.

${ }^{10} \mathrm{Ibi}$, p. 3f.
} 
when the balance for most WTO members lay firmly on the side of trade liberalization ${ }^{11}$. The WTO count does not include trade measures in the context of swine flu (influenza A virus H1N1). A more recent report by the WTO of November $2009^{12}$ confirms that there has been 'policy slippage' - a term frequently used by the WTO to describe the on-going erosion of trade disciplines among its members.

\subsection{Protectionist trends in detail}

Data available in the Global Trade Alert database per 20 January 2010 includes 670 policy measures that have been examined by the GTA team. Of this total, 457 measures have already been implemented, whereas another 213 measures are still pending. The database groups these measures into three categories: The category 'red measures' denotes measures that have been implemented and almost certainly discriminate against foreign commercial interests. The category 'amber measures' encompasses measures which either (i) have been implemented and may involve discrimination against foreign commercial interests; or (ii) measures which have been announced or are under consideration and would (if implemented) almost certainly involve discrimination against foreign commercial interests. The category 'green measures' includes measures that have been announced and involve liberalisation on a non-discriminatory (i.e. most favoured nation) basis; or (ii) measures which have been implemented and are found (upon investigation) not to be discriminatory: or (iii) measures which have been implemented, involving no further discrimination, and improving the transparency of a jurisdiction's trade-related policies.

From an analysis of the measures included in the database, we may derive the following findings.

\subsubsection{Implementing jurisdictions}

Most measures emanate in the EU if we add both the measures taken on the EU level and the measures taken by all the $27 \mathrm{EU}$ members on the national level.

\footnotetext{
${ }^{11}$ See World Trade Organisation (ed.), Report to the TPRB from the Director-General on the Financial and Economic Crisis and Trade-Related Developments, WTO, Document No. WT/TPR/OV/W/1, Geneva, 20 April 2009a. Available at http://docsonline. wto.org/DDFDocuments/t/WT/TPR/OVW1.doc, p. 2.

${ }^{12}$ See WTO, Overview of Developments.
} 
If, by contrast, we count the measures on a country basis, a different picture emerges: In this case, most measures are taken by Russia, the United States, India, and Argentina. The first EU member on the list is Germany (when adding both the measures taken by the EU and the measures taken by Germany on the national level), slightly ahead of Brazil, a few other EU countries, and China. Overall, it seems that G-20 countries implement a higher share of beggar-thy-neighbour policies than other countries.

Figure 1 - Jurisdictions implementing most measures

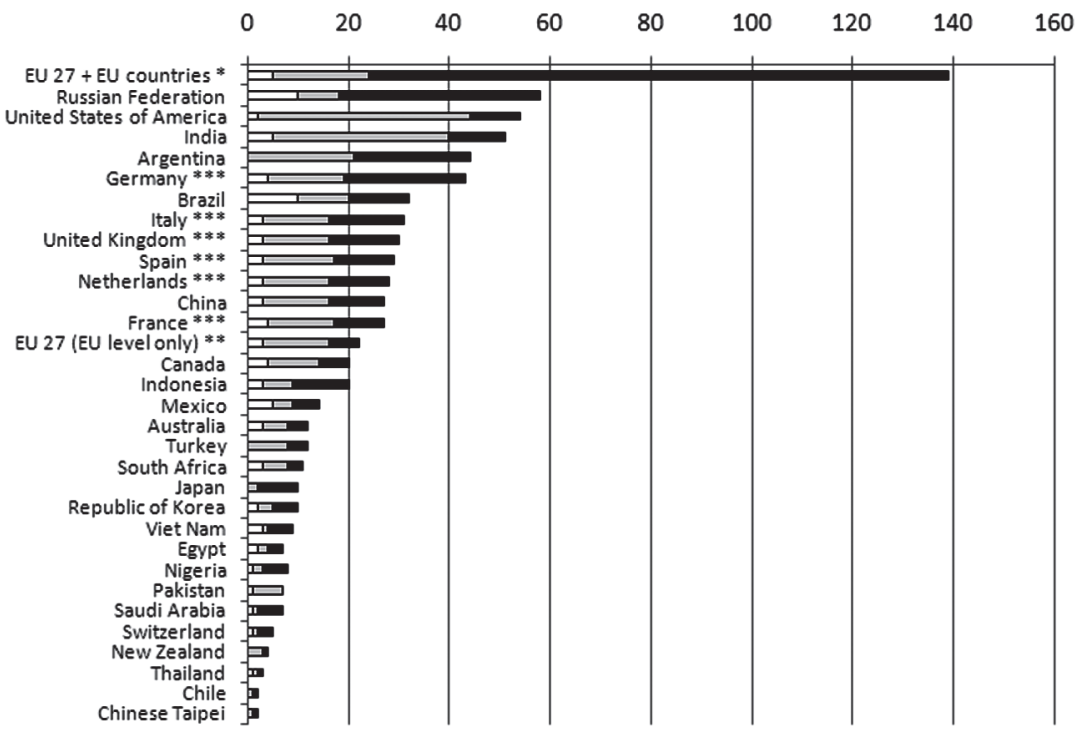

$\square$ Green measures in database $\square$ Amber measures in database $\quad$ Red measures in database

Graph by Thomas A. Zimmermann; Statistical data drawn from the 'Global Trade Alert' database per 20 January 2010; http://www.globaltradealert. org. Remarks*); The bar 'EU 27 + EU countries' counts both the measures taken by the EU on the Union level and the national measures of all EU members**); The bar 'EU 27 (EU level only)' counts only the measures taken by the EU on the Union level***); The bars for the individual EU member countries count both the measures taken by the EU on the Union level and the national measures taken by the corresponding EU member at the national level. 


\subsubsection{Jurisdictions affected}

China is the most frequent target of the protectionist measures taken, followed by Germany, the U.S., France, Italy and Japan. It is noteworthy that countries such as Russia or Argentina, that are themselves very active in taking protectionist measures, appear further behind on the list of jurisdictions affected.

Figure 2 - Jurisdictions most affected by measures

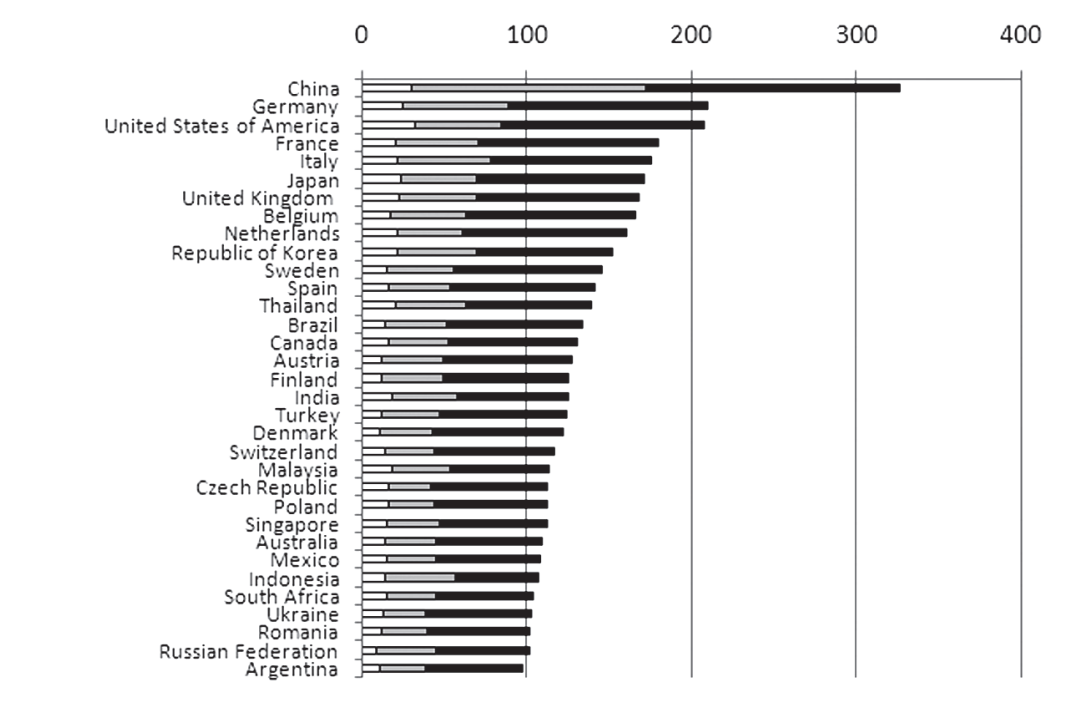

$\square$ Green measures in database

$\square$ Amber measures in database

Red measures in database

Graph by Thomas A. Zimmermann; Statistical data from the 'Global Trade Alert' database per 20 January 2010; http:/ /www.globaltradealert.org

\subsubsection{Trade policy measures used}

The most frequently used types of measures are trade defence measures (i.e. antidumping, countervailing duties, safeguards), followed by bailouts and state aids (mainly in OECD countries; these are discussed in Chapter 4 of this paper), as well as tariff increases. Also high on the list, though with a much lower frequency, are measures in public procurement (such as 'buy national' rules), investment measures, non-tariff barriers, export taxes and restrictions, export subsidies, local content 
rules, services sector measures, as well as sanitary and phytosanitary measures (Graph 3).

Figure 3 - Measures used most frequently

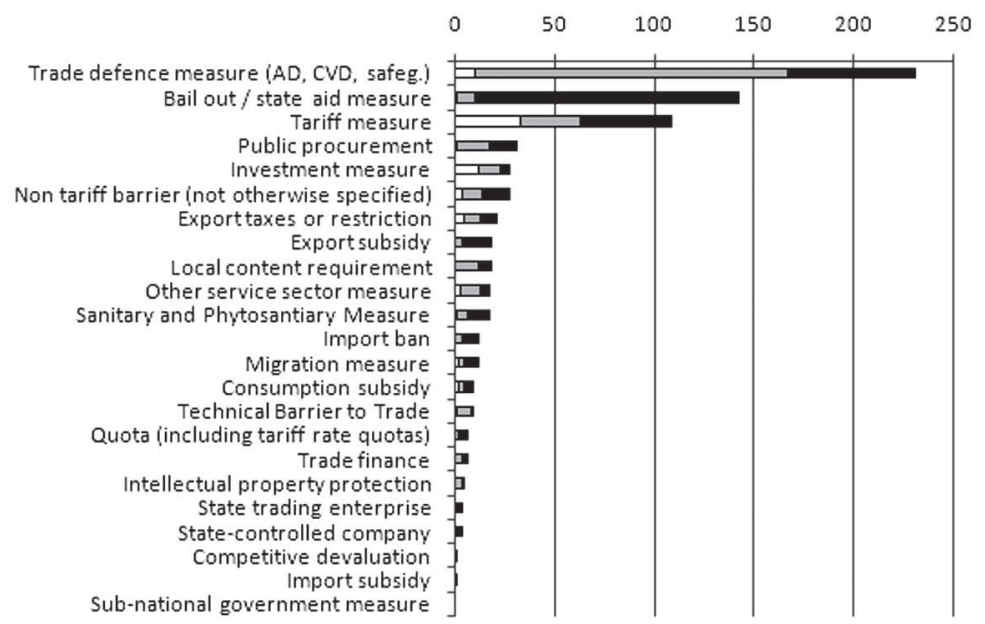

$\square$ Green measures in database $\square$ Amber measures in database $\square$ Red measures in database

Graph by Thomas A. Zimmermann; Statistical data from the 'Global Trade Alert' database per 20 January 2010; http:/ /www.globaltradealert.org

In detail, the different types of trade policy measures have been used as follows:

Anti-dumping actions: After having declined between 2001 and 2007, the number of anti-dumping actions has recently increased. Between 1 July 2008 and 30 June 2009, the number of new antidumping initiations reported to the WTO by Members increased by $15 \%$ in relation to the preceding 12 month period. Comparing antidumping actions in the first six months of 2009 with anti-dumping actions in the first six months of 2008, one finds that the landscape of countries applying such actions has strongly changed. Whereas the number of anti-dumping actions in the EC and in the U.S. was down from 15 to 2 and from 14 to 10 respectively, the number of actions by China and Argentina was up from 3 to 14 and from 14 to 19 respectively. This reinforces the impression that developing countries are increasingly having recourse to this trade defence instrument, often targeting exports of other developing countries. The product categories targeted most often are metals, chemicals, and plastics. Analysts 
expect a strong increase in the number of anti-dumping actions in the coming quarters as the investigations react with a certain timelag to a deterioration of the economic situation, given the need to run through time-consuming procedures. Based on an econometric model, analysts expect a strong increase of anti-dumping initiations in coming months ${ }^{13}$.

Countervailing Duty (CVD) Measures: The WTO reports a significant increase of countervailing duty investigations. It notes that most recent CVD investigations have been initiated simultaneously with anti-dumping investigations. Based on trends and figures in the first three quarters of 2009, the total number of CVD investigations in 2009 could surpass the 1999 record of 41 investigations. As in the case of anti-dumping investigations, CVD investigations focus primarily on metals, chemicals and plastics. Unlike anti-dumping, CVD action is mainly used by developed countries ${ }^{14}$.

Safeguards: The number of safeguard investigations has also risen strongly since the $4^{\text {th }}$ quarter of 2008. Up to the end of October 2009, the WTO recorded 26 safeguard investigations, i.e. the second highest number since 2002. Most investigations focussed on chemicals, cement/glass/ceramics, animal products, and metals. India was one of the most frequent users ${ }^{15}$.

Tariff and NTB increases: Tariffs and non-tariff barriers (NTBs) have increased on a wide range of imports, especially on agricultural products, iron and steel, motor vehicles and parts, chemical and plastic products, and textiles and clothing ${ }^{16}$.

Reintroduction of agricultural subsidies: Among the measures we find the re-introduction of agricultural subsidies in the European Union and the United States (dairy) and a recent increase of such subsidies (price adjustment mechanism) in Switzerland ${ }^{17}$.

'Sand in the gears': stricter application of SPS and TBT regulations in some G-20 markets, slower procedures and additional procedural requirements in the administration of existing trade measures ${ }^{18}$.

${ }^{13}$ See WTO, Overview of Developments, p. A-28f. On the econometric model, see WTO, Report to the TPRD, pp. $20 \mathrm{ff}$.

${ }^{14}$ For details, see WTO, Overview of Developments, p. A-29, and the GTA database.

${ }^{15} \mathrm{Ibi}$, p. A-29f., and the GTA database.

${ }^{16} \mathrm{Ibi}$, pp. A-23ff., and the GTA database.

17 See Bundesamt FÜr Landwirtschaft, Bundesrat unterstützt Massnahmen der Landwirtschaft zur Stabilisierung der Märkte, Press release, 2009.

${ }^{18}$ See Organisation for Economic Co-operation and Development (OECD) - World Trade Organisation (WTO) - United Nations Conference on Trade and Development 


\subsubsection{Sectors affected}

As becomes apparent from an analysis of the individual measures, the sectors that benefit the most from protectionist interventions are declining industrial sectors and agriculture: basic metals and basic chemicals - two sectors characterised by substantial overcapacities are the two sectors most heavily affected by protectionist measures. Moreover, special purpose machinery, transport equipment, fabricated metal products, food products, other chemical products, glass and textiles are also concerned. Among services sectors, financial services are the single sector most affected by government measures. Nearly all measures in this sector are estimated to be protectionist in nature and have therefore been grouped by GTA into the 'red' category (see Graph 4 for details).

The financial services sector is of paramount importance since it also has a strong link to investment policy, and to capital markets and capital movements in general. It is also affected by the current trend towards a re-regulation and by the tax spats that have emerged in 2008 and 2009 (see Chapter 3 and Section 4.4 of this paper for more details).

There are several reasons why financial services have been particularly hit by the recourse to economic interventionism. First, financial services and portfolio investments often enjoy a lower degree of protection against arbitrary state interventions under international agreements. Second, rescue packages and bailout actions for financial institutions may lead to a partial or total nationalization of the institutions concerned, potentially leading to issues under international agreements and/or conflicts with international investors which could give rise to the perception that foreign investors are treated less favourably than domestic investors, if only for a lack of political clout in the host country. And third, financial sector regulation may have an adverse impact on foreign investors. By consequence, international investment agreements sometimes include 'prudential carve-out provisions', establishing that nothing in the agreement shall prevent the right of the contracting parties to adopt or maintain prudential measures $^{19}$.

(UNCTAD) (eds.), Report on G20 Trade and Investment Measures, OECD, Paris, 2009. Available at http://www.oecd.org/dataoecd/56/48/43689944.pdf, p. 11.

${ }^{19}$ See also United Nations Conference on Trade and Development (UNCTAD) (ed.), World Investment Report - Transnational Corporations, Agricultural Production and Development, UNCTAD, New York - Geneva 2009. Available at http://www.unctad. org/en/docs/wir2009_en.pdf, p. 36. 
Figure 4 - Sectors most affected by measures

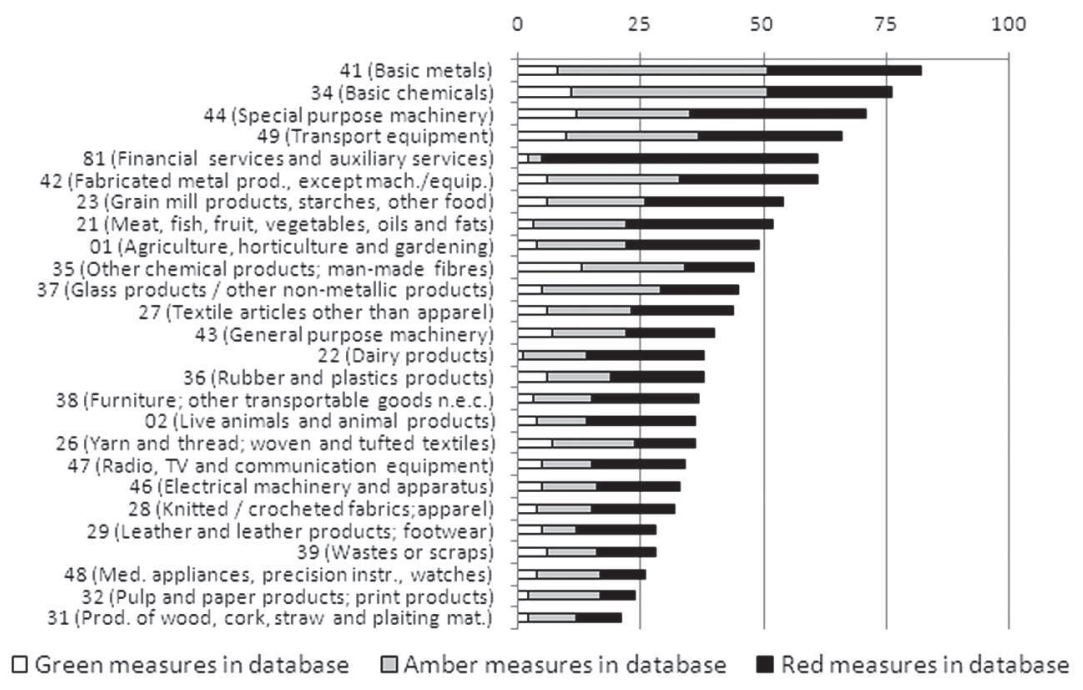

Graph by Thomas A. Zimmermann; Statistical data from the 'Global Trade Alert' database per 20 January 2009; http:/ /www.globaltradealert.org

2.3. Trade negotiations with little progress

Besides the many trade policy measures that make life harder for private economic actors in international trade, other aspects reinforce the impression that trade liberalisation is currently not high on the agenda of policymakers.

On the multilateral level, the low momentum in trade negotiations under the Doha Round can be mentioned as an example. There is no indication that the Round will be concluded any time soon. In summer 2008, hopes for some compromise at an informal ministerial conference were deceived. Expectations are by now very low (and are being kept very low by negotiators and by the WTO itself). The WTO Ministerial Conference that took place in November/ December 2009 in Geneva did not even have the purpose of advancing the negotiations - despite the slow progress and the fact that this was the first official WTO Ministerial Conference since 'Hong Kong' in 2005. Besides two minor practical results - extensions of a moratorium regarding tariffs on e-commerce and of a moratorium on TRIPS 
non-violation complaints - the ministers merely agreed to engage in a stocktaking exercise in spring 2010 and to hold their next regular Ministerial Conference in late 2011.

Another indicator of the low priority accorded to trade issues is the current U.S. trade policy under the Obama administration. After nearly one year in office, the Administration appears to focus most of its attention on domestic policy issues, such as health care reform. Despite lukewarm rhetoric to the contrary, the administration has not yet come forward with a clear trade strategy - neither for the three pending FTAs negotiated by the Bush Administration which still await Congressional approval (Korea, Panama, Colombia), nor for the multilateral Doha Round ${ }^{20}$.

\subsection{Some green sprouts: instances of trade liberalisation}

On the positive side, a few countries have also made moves towards more liberalisation. For instance, Brazil, China, India, Indonesia, Mexico, the Russian Federation and Saudi Arabia announced cuts in import duties, fees and surcharges and the removal of non-tariff barriers on various products (with some of these countries, however, raising trade restrictions - mostly import tariffs - as well). Similarly, a few countries (e.g. Australia) have terminated anti-dumping measures, anti-dumping investigations, and countervailing investigations. In services, a positive trend is the generally ongoing liberalisation of ICT (Information and Communications Technology) industries. Yet, as noted both by EvEnETT and the WTO (see above), the overall number of more restrictive measures is (much) larger than the number of liberalising measures.

Another positive (or ambiguous, as critics might argue) point is the continued negotiation of free-trade agreements (FTAs) by many countries other than the U.S. ${ }^{21}$. Although these preferential trade

\footnotetext{
${ }^{20}$ For recent criticism of the current administration in this respect, see for instance the articles published in the following editions of the Washington Trade Daily (WTD): 4 December 2009, 'Trade and Foreign Policy'; 3 December 2009, 'Where's the Trade Agenda?' and 'Trade and Jobs - And the Summit; 2 December 2009: First Report in the 'Around the Globe' section.

${ }^{21}$ Recent examples include Swiss FTAs with Albania (signed on 17 December 2009), Serbia (signed on 17 December 2009) and with the Gulf Cooperation Council (GCC; signed on 22 June 2009); the EU-Korea FTA (initialed on 15 October 2009); the India-Korea Comprehensive Partnership Agreement (CEPA; signed in August 2009); the India-ASEAN FTA (signed in August 2009), the ASEAN-Australia-New Zealand FTA (signed in February 2009); the Canada-Colombia FTA (signed on
} 
pacts will barely move the multilateral trading system forward, they provide instances of trade liberalisation and additional security for traders in an environment that is characterised by a more protectionist climate. Obviously, critics of FTAs might argue that the trade-distorting effects of FTAs may be larger than their trade-creating effects, and that FTAs increasingly lead to a fragmentation of the world trading system, doing more harm than good. A detailed discussion of this issue is beyond the scope of this paper ${ }^{22}$.

\section{Investment policies ${ }^{23}$}

3.1. Overall assessment: Liberalisation dominates, but loses momentum

International investment activity has been strongly affected by the financial and economic crisis. According to figures released by UNCTAD in January 2010, foreign direct investment (FDI) inflows have fallen sharply from their record high close to 2.0 trn USD in 2007 to little over 1.0 trn USD in 2009. Contrary to 2008, when FDI inflows to developed countries fell and inflows to developing and transition economies still increased, all world regions suffered from

21 November 2008). Agreements that entered into force in the second half of 2009 are the FTAs between Japan and Vietnam (1 October 2009), the EC and Cameroon (1 October 2009), Japan and Switzerland (1 September 2009), Peru and Singapore (1 August 2009), Canada and Peru (1 October 2009), and Canada - EFTA (1 July 2009). This footnote is based on information available at the following sources: website http://www.bilaterals.org, WTO (http://rtais.wto.org/ UI/PublicMaintainRTAHome.aspx), and SECO (http://www.seco.admin.ch/ themen/00513/00515/01330/index.html?lang=de).

22 See H. Hauser - T.A. Zimmermann, Regionalismus oder Multilateralismus? «Die Volkswirtschaft» 74 (2001), 5, pp. 4-8. Available at http://www.zimmermannthomas.de/publikationen/vw0105d4.pdf, for an introduction to this debate and further references.

${ }^{23}$ Unless otherwise specified, the factual information presented in this chapter is based mainly on United Nations Conference on Trade and Development (UNCTAD) (ed.), World Investment Report - Transnational Corporations, Agricultural Production and Development, UNCTAD, New York-Geneva 2009. Available at http://www.unctad.org/en/docs/wir2009_en.pdf, as well as OECD, UNCTAD and WTO, Report on G20. 
the decline in 2009. UNCTAD expects a slow recovery in 2010, and a subsequent acceleration in $2011^{24}$.

Contrary to the trend in trade policies, investment policies continued to be characterised by a dominant trend towards liberalisation. According to the UNCTAD database on national laws and regulations, the measures that are more favourable to FDI clearly outnumber the measures that are less favourable to FDI (see Figure 5). Nevertheless, the share of regulatory changes that are less favourable to FDI has risen from $2 \%$ in the year 2000 to $20 \%$ and above since 2005 (see Figure 6).

Figure 5 - National Regulatory Changes, 1992-2008

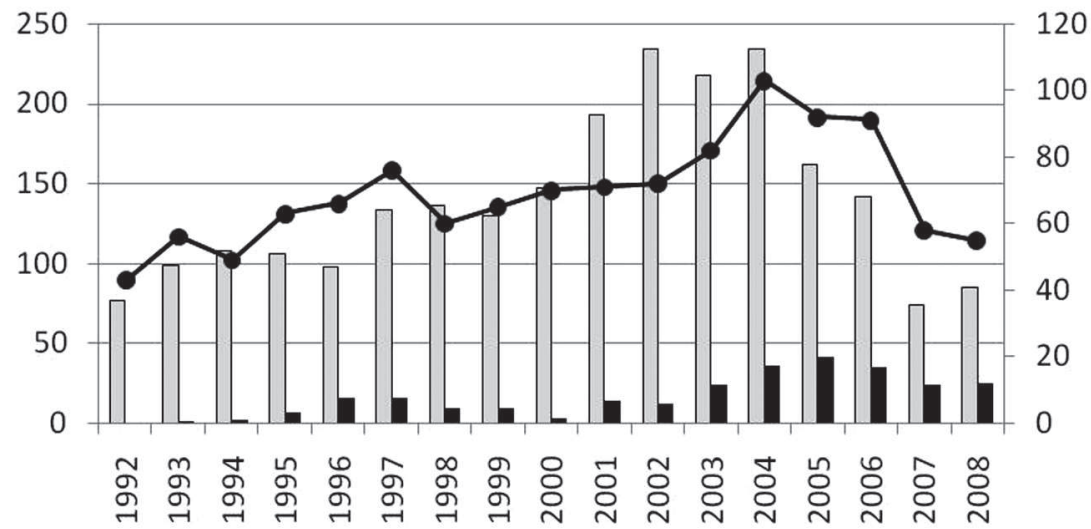

Number of regulatory changes more favourable to FDI (left axis)

Number of regulatory changes less favourable to FDI (left axis)

$\rightarrow-$ Number of countries that introduced change (right axis)

Graph by Thomas A. Zimmermann; Data source: UNCTAD, World Investment Report 2009, pp. 31.

${ }^{24}$ See UNCTAD, World Investment Report 2009, pp. xxvii, xix and 3, and UniteD Nations Conference on Trade and Development (UNCTAD) (ed.), Global and Regional FDI Trends in 2009 «Global Investment Trends Monitor», 2, UNCTAD, Geneva 19 January 2010. Available at http://www.unctad.org/Templates/Download.asp? docid=12609\&lang=1\&intItemID=2068ed. 
Figure 6 - Share of less favourable regulatory changes in percent of all regulatory changes, 1992-2008

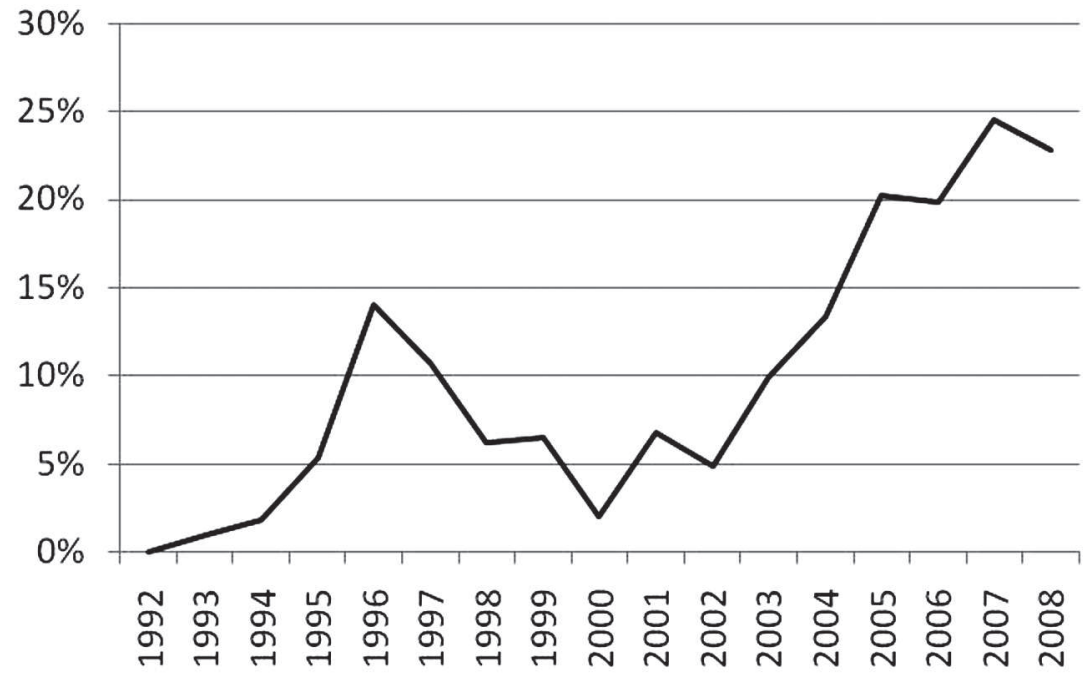

-FDI: Share of less favourable regulatory changes in \% of all regulatory changes

Graph by Thomas A. Zimmermann; Data source: UNCTAD, World Investment Report 2009, pp. 31.

Judged by the numbers, the highest rate of more favourable regulatory changes to FDI in 2008 (as a percentage of all regulatory changes in the respective region) was recorded for developed countries, with $91 \%$. The lowest rate of favourable regulatory changes was recorded in Latin America (55\%), where some countries took further steps to nationalize strategic industries - extractive industries in particular. The trend towards more state interventions and more restrictive policies towards FDI has been noted for several years already and could be considered a reflection of the increase in the number of left-leaning governments in Latin America that are sceptical of foreign investors.

According to the rather cautious wording in $\operatorname{UNCTAD}$ (2009, p. 30), «[... ] so far, the current financial and economic crisis has had no major impact on FDI policies per se». The same report even goes on to say that the economic stimulus packages, including public investment programmes, may have a positive impact on FDI, provided that they are administered in a non-discriminatory manner and open to participation 
by foreign investors. Yet, the report also notes that «some countries have begun to discriminate against foreign investors and/or products in a 'hidden' way using gaps in international regulations». Examples of such 'covert' protectionism include favouring products with high domestic content in public infrastructure projects, preventing banks from lending for foreign operations, invoking 'national security' exceptions, or moving protectionist barriers to the sub-national levels.

\subsection{Protectionist trends in investment policies}

Among the recent policy trends with a potentially protectionist impact, we note ${ }^{25}$ :

The denunciation of bilateral investment treaties (BITs): Ecuador has denounced nine BITs. In addition, a BIT between El Salvador and Nicaragua, and another BIT between the Netherlands and Venezuela have been denounced, too. These denunciations may reflect a new reluctance towards BITs, particularly in Latin America.

Nationalisations: Several nationalizations have taken place in Latin America, particularly in the extractive industries, the telecommunications industry, and the oil and gas industry in Bolivia; the cement industry in Venezuela; the pension system in Argentina.

Increased scrutiny of FDI for national security reasons: Among these measures is the authorisation of the Committee on Foreign Investments in the United States (CFIUS) to review transactions that could result in control of a U.S. business by a foreign person. This went along with an increase in the number of cases reviewed in the U.S. Similarly, an amendment to the German Foreign Trade and Payments Act grants the Federal Ministry of the Economy and Technology the right to initiate a review of foreign investments and to exceptionally prohibit transactions that threaten to impair public security or public order. In Canada, the Investment Canada Act authorises the government to review investments that impair or threaten to impair national security. A noteworthy development in France is the establishment of a new public fund which will be run by the French Government and the Caisse des Dépôts et Consignations (CDC) and which could shield national firms from foreign takeovers.

Adverse tax developments: Taxes have risen, for instance in the mining industry (e.g. in Zambia), or in Ecuador, which taxes windfall profits on oil up to $99 \%$.

${ }^{25}$ For details on these and other measures, see UNCTAD, World Investment report 2009, as well as OECD, UNCTAD and WTO, Report on G20. 
New restrictions for foreign investors: Some countries have introduced new bans on foreign investors - e.g. an Indonesian ban on foreign investment in the construction and ownership of wireless communications towers.

Other measures: These include, for instance, discrimination against foreign investors in stimulus / bailout packages, or the prevention of bank lending for foreign operations. Among other measures, we also note competition regulation (e.g. a reservation of intermediation in the supply of liquid fuels between the state-owned Venezuelan oil company PDVSA and the state); Ecuador's withdrawal from the Convention of the International Centre for Settlement of Investment Disputes (ICSID); or the expansion of the definition of 'strategic industries' in Russia to 42 industries.

\subsection{Instances of liberalisation in investment policies}

As noted above in the general introduction, and despite the protectionist measures described in section 3.2 above, the share of measures facilitating investments still dominates. The following trends are noteworthy:

Conclusion of new agreements facilitating international investment: Since the beginning of the crisis, countries have continued to conclude new Bilateral Investment Treaties (BITs), Double Taxation Treaties (DTTs), and other international investment agreements (including Free-Trade Agreements with investment provisions).

A softer stance towards Sovereign Wealth Funds (SWFs): Sovereign wealth funds (SWFs) had come under close scrutiny in recent years and were increasingly threatened with protectionist measures. OECD countries have, however, recently recognised the benefits unfolding from SWF activities more explicitly, and protectionist pressures in this respect have somewhat decreased. At the same time, SWFs have increased their efforts towards transparency (see Box 1 with details on this issue).

Various other measures aiming at liberalisation: These include: raised or abolished FDI ceilings or foreign equity limits (e.g. India, Malaysia); eased or streamlined licensing and review processes (e.g. China, Australia); eased requirements for the purchase of real estate by foreigners or easier access to land (e.g. Australia, Korea, Mexico); tax reductions and simplifications (e.g. Kuwait, Georgia, Switzerland, Japan); liberalisations of the exchange rate regime and external financing conditions (e.g. Syria); privatizations (e.g. utilities in Kenya, an airline in Kuwait, a petroleum company in Jordan, large privatizations in Turkey); improvements of the competition regulation (e.g. Mauritius); lifted monopolies (e.g. fix line 
monopolies in Oman and Qatar); relaxation of visa requirements (Saudi Arabia); facilitation in investment in Indian depository receipts.

\section{BOX 1 - SOVEREIGN WEALTH FUNDS (SWFS)}

In the last few years, protectionist sentiment in the area of international investment had risen in particular in the context of Sovereign Wealth Funds (SWFs). Their activities increased massively in the boom years between 2005 and 2008, attracting widespread criticism and arousing suspicion in developed countries. A perceived lack of transparency of SWFs, the fact that many SWFs are domiciled in countries that are considered authoritarian, and a fear that SWFs might pursue political instead of economic goals and thus threaten the national security of host countries, were among the main reasons for this criticism. The scepticism towards SWFs became particularly virulent during the boom years of 2007 and early 2008. Since the unfolding of the financial crisis, the criticism about SWFs has somewhat muted: As SWFs had massively invested in the financial industry, their capital participation was increasingly considered a welcome contribution to the stabilization of financial markets when conditions deteriorated. At the same time, the value of SWF portfolios decreased due to lower stock market valuations - in particular as many SWFs had previously focused their investments on the hard-hit financial sector of developed countries. Furthermore, the funds available for international investments diminished, since their main capital sources - high resource prices and export surpluses - dried up and SWF investments were increasingly directed to their home markets.

A further reason for the moderation in the criticism of SWFs, however, was the policy reaction on the side of home countries and host countries. SWFs increasingly worried about the dismissive response towards their activities in developed countries. On 1 May 2008, an International Working Group (IWG) of Sovereign Wealth Funds was established. This initiative, which was backed by key SWFs and facilitated by the International Monetary Fund (IMF), agreed on 'Generally Accepted Principles and Practices' (GAPP), the so-called 'Santiago principles' on 11 October 2008. The GAPP are based on four guidelines: (i) to help maintain a stable global financial system and free flow of capital and investment; (ii) to comply with all applicable regulatory and disclosure requirements in the countries in which they invest; (iii) to invest on the basis of economic and financial risk and return-related considerations; and (iv) to have in place a transparent and sound governance structure that provides for adequate operational controls, risk management, and accountability. In its 'Kuwait Declaration' of 6 April 200926, the IWG established the 'International Forum of Sovereign Wealth Funds' (IFSWF) whose purpose it is to exchange views on issues of common interest and facilitate an understanding of the GAPP. In its 'Baku Declaration' of 9 October 2009, the IFSWF reaffirmed its commitment, inter alia, to «encourage recipient countries to continue making their investment regimes more transparent and non-discriminatory, avoid protectionism,

${ }^{26}$ See http://www.iwg-swf.org/mis/kuwaitdec.htm. 
and foster a constructive and mutually beneficial investment environment». On the side of the host countries, OECD Ministers adopted, on 5 June 2008, a declaration in which they held that «[...] recipient countries should not erect protectionist barriers to foreign investment» and that they «should not discriminate among investors in like circumstances». According to the declaration, "[...] any additional investment restrictions in recipient countries should only be considered when policies of general application to both foreign and domestic investors are inadequate to address legitimate national security concerns. Where such national security concerns do arise, investment safeguards by recipient countries should be transparent and predictable, proportional to clearly-identified national security risks, and subject to accountability in their application $x^{27}$. This declaration draws upon the recognition that SWFs bring benefits to both home and host countries, and that national security concerns - though legitimate - should not be a cover for protectionist policies, as recognised in a previously issued report by the OECD of April $2008^{28}$.

Finally, on 16 July 2009, G-20 members who are also members of the OECD, agreed, using standstill procedures established under the legally binding OECD Codes of Liberalisation ${ }^{29}$, to lock in recent measures that liberalise inward and outward foreign investment.

Overall, UNCTAD (2009, p. 36) holds that «recent policy developments paint a comforting picture». Nevertheless, there are fears that economic stimulus programs could give rise to 'covert protectionism' by discriminating against foreign investors, and that a spreading of the crisis to so-far unaffected sectors could increase protectionist pressures. Moreover, UNCTAD fears that the withdrawal of the State from bailed-out* flagship industries could spur economic nationalism if foreign investors were to purchase firms that are considered 'national champions'.

27 See Organisation for Economic Co-operation and Development (OECD) (ed.), OECD Declaration on Sovereign Wealth Funds and Recipient Country Policies, adopted by Ministers of OECD countries at the Council at Ministerial level, 5 June 2008, Document C/MIN(2008)8/FINAL. Available at http://www.olis.oecd.org/ olis/2008doc.nsf/LinkTo/NT000032DE/\$FILE/JT03247225.PDF.

28 See Organisation for Economic Co-operation and Development (OECD) (ed.), Freedom of Investment, National Security and 'Strategic' Industries - Sovereign Wealth Funds and Recipient Country Policies - Report by the OECD Investment Committee, OECD, Paris, 9 April 2008, Document DAF/INV(2008)5/REV1). Available at http://www. olis.oecd.org/olis/2008doc.nsf/ENGDATCORPLOOK/ NT00000EE6/\$FILE/ JT03243871.PDF. See p. 4 (Box 1) and p. 8 (References) for more details on the OECD Acquis in the area of international investment.

${ }^{29}$ OECD - Modifications of OECD Countries' Positions under the Codes of Liberalisation of Capital Movements and of Current Invisible Operations and the National Treatment Instrument, 16 July 2009. 


\section{Fiscal policies}

4.1. Overview: Fiscal policy as a major area of economic interventionism

During the 2007-2009 financial crisis, fiscal policies have provided governments with important instruments for economic interventionism. The two most important ones are stimulus programs with a view to propping up demand in an otherwise sluggish economy, and treasurysponsored emergency schemes for ailing banks and other industries (e.g. the car industry).

Such policies can lead to dual distortions: On the one hand, channelling government funds into specific sectors alters the pattern of supply and demand as well as capital allocation that would otherwise prevail. On the other hand, government expenditures or government-sponsored bailout measures may come along with protectionist conditions or pressures. Examples include 'lend local' requirements for bailed-out banks, 'buy national' provisions in public procurement, or pressures to maintain a certain level of national production in assistance schemes for the car industry.

\subsection{Stimulus programs}

Countries have used a variety of stimulus measures to prop up demand in the current crisis. These measures have been taken both on the revenue side (through tax cuts) and, to a larger degree, on the expenditure side by increased public spending.

Regarding increased expenditure, the most frequently used instruments have been the provision of safety nets, infrastructure investment, as well as housing and construction support. Stimulus measures have also included targeted aid to small- and medium-sized enterprises (SMEs), strategic industries, and farmers.

On the revenue side, governments have eased the tax burden for both corporate and personal income taxes. Whereas most of the measures on the expenditure side have been crafted to be temporary, it is interesting to note that several stimulus measures on the government's revenue side have a permanent character, particularly as far as corporate income tax measures are concerned. These measures will continue to weigh on government budgets even once the crisis is over (see figure 7 for details). 
Figure 7 - G-20 Stimulus Measures, 2008-2010

\begin{tabular}{|c|c|c|c|c|c|c|c|c|c|c|c|c|c|c|c|c|c|c|c|c|}
\hline Measure & 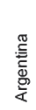 & 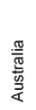 & $\begin{array}{l}\overline{\mathbb{K}} \\
\bar{\infty} \\
\infty\end{array}$ & 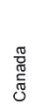 & $\frac{\mathbb{5}}{\bar{E}}$ & 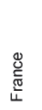 & 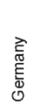 & $\underline{\underline{\underline{w}}}$ & 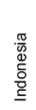 & $\stackrel{\frac{2}{\underline{\underline{\pi}}}}{\underline{2}}$ & 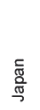 & 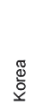 & $\begin{array}{l}\stackrel{\mathscr{O}}{\bar{x}} \\
\stackrel{0}{\Sigma}\end{array}$ & 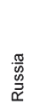 & 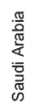 & 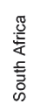 & 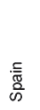 & 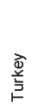 & 弚 & כ) \\
\hline \multicolumn{21}{|l|}{ Expenditure } \\
\hline $\begin{array}{l}\text { Infrastructure investment } \\
\text { Support to SMEs and/or farmers }\end{array}$ & $T$ & T & & $\begin{array}{l}\mathrm{T} \\
\mathrm{T}\end{array}$ & $\mathrm{T}$ & $\mathrm{T}$ & T & $T$ & $\mathrm{~T}$ & T & $\begin{array}{l}T \\
T\end{array}$ & $\begin{array}{l}\mathrm{T} \\
\mathrm{T}\end{array}$ & T & $T$ & T & T & T & T & s & $T$ \\
\hline Safety nets & $T$ & $T$ & $T$ & $\mathrm{~T}$ & $T$ & $T$ & P & $T$ & $\mathrm{~T}$ & T & $T$ & $T$ & T & $T$ & & $T$ & $T$ & T & $T$ & $T$ \\
\hline $\begin{array}{l}\text { Housing/construction support } \\
\text { Strategic industries support } \\
\text { Increase in public wage bill }\end{array}$ & & T & T & $\begin{array}{l}\mathrm{T} \\
\mathrm{T}\end{array}$ & $\begin{array}{l}\mathrm{T} \\
\mathrm{T}\end{array}$ & $\mathrm{T}$ & $\begin{array}{l}P \\
T\end{array}$ & $\mathrm{~T}$ & & $\begin{array}{l}\mathrm{T} \\
\mathrm{T}\end{array}$ & T & $\mathrm{T}$ & & $\begin{array}{l}\mathrm{T} \\
\mathrm{T}\end{array}$ & & $T$ & $\begin{array}{l}\mathrm{T} \\
\mathrm{T}\end{array}$ & $\mathrm{T}$ & $T$ & \\
\hline Other & & T & $\mathrm{T}$ & $\mathrm{T}$ & $\mathrm{T}$ & $\mathrm{T}$ & T & $\mathrm{T}$ & $\mathrm{T}$ & $\mathrm{T}$ & $T$ & $\mathrm{~T}$ & T & T & & & T & T & $\mathrm{T}$ & $\mathrm{T}$ \\
\hline \multicolumn{21}{|l|}{ Revenue } \\
\hline $\mathrm{CIT} /$ depreciation/incentives $2 /$ & & T & $P$ & P & & & P & & P & $P$ & P & $\mathrm{P}$ & & $P$ & & & & P & & $P$ \\
\hline PIT/exemptions/deductions $3 /$ & $\mathrm{P}$ & & $\mathrm{T}$ & $\mathrm{P}$ & & $\mathrm{T}$ & $\mathrm{P}$ & & $\mathrm{P}$ & $\mathrm{T}$ & $\mathrm{P}$ & $\mathrm{P}$ & & $\mathrm{P}$ & & & $\mathrm{P}$ & $\mathrm{P}$ & $\mathrm{P}$ & $\mathrm{P}$ \\
\hline Indirect tax reductions/exemptions 4 / & $\mathrm{P}$ & & $\mathrm{T}$ & & $\mathrm{P}$ & $\mathrm{P}$ & $P$ & T & $\mathrm{P}$ & $\mathrm{T}$ & & $\mathrm{T}$ & & & & & $\mathrm{s}$ & T & s & \\
\hline Other & & T & & & & & & & & $\mathrm{P}$ & $\mathrm{P}$ & $\mathrm{T}$ & & & & & & $\mathrm{P}$ & $\mathrm{P}$ & \\
\hline
\end{tabular}

Sources: Country authorities; and IMF staff estimates.

Note: $T=$ temporary measures (with explicit sunset provisions or time-bound spending); $S=$ self-reversing measures

(measures whose costs are recouped by compensatory measures in future years); and $\mathrm{P}=$ permanent measures (with recurrent fiscal costs).

$1 /$ Measures announced through early May 2009.

2/ Some of the corporate income tax (CIT) reductions in Germany, Italy, and Korea are temporary.

Source: IMF (2009b), p. 17.

Figure 8 - G-20: Countries: Estimated Cost of Discretionary Measures taken between 2008 and 2010; in \% of GDP, relative to 2007 baseline)

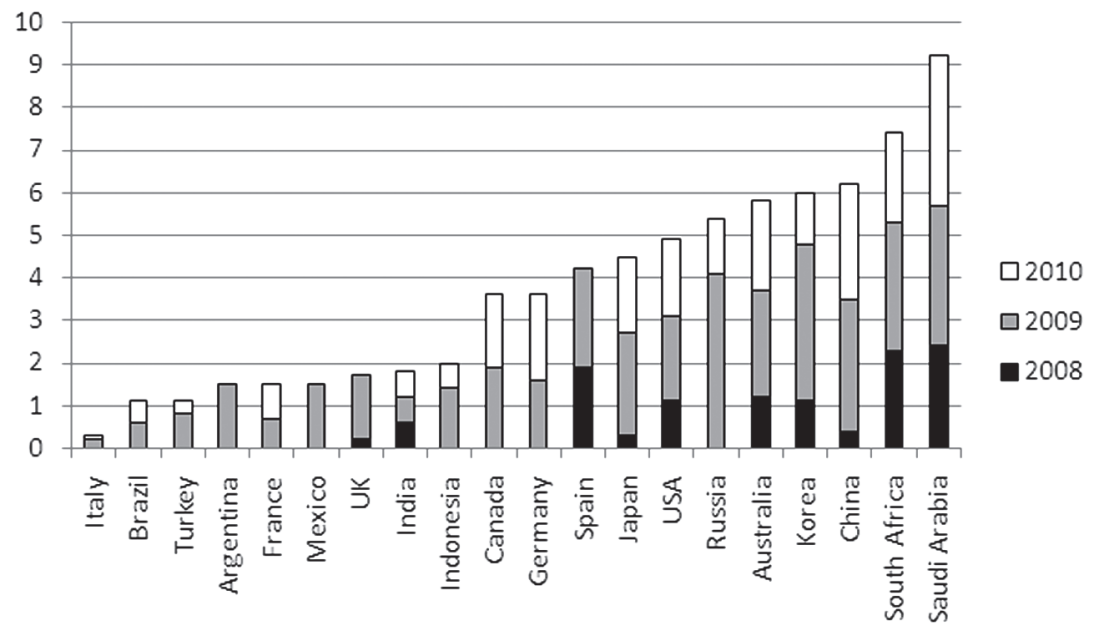

Graph: Thomas A. Zimmermann; data source: International Monetary Fund (IMF) ed. (2009): Fiscal Implications of the Global Economic and Financial Crisis; IMF Staff position note SPN/09/13, 9 June 2009, Table 3.4, p. 15. 
The volume of the stimulus measures is quite substantial. The cumulative size of the support measures taken in 2008, 2009 and 2010 amounts to roughly $3.7 \%$ of GDP in the year 2007 on average for the G-20 countries, ranging from $0.3 \%$ in the case of Italy up to $9.2 \%$ in the case of Saudi Arabia. The average yearly size of the stimulus measures in G-20 countries was $0.6 \%$ of GDP in 2008, $1.9 \%$ in 2009 , and $1.2 \%$ in 2010, according to numbers published by the IMF in June 2009 (see Figure 8).

\subsection{Emergency actions: Support to the Financial Sector}

Another domain of fiscal policy - with an even much larger impact on public finances than that of the stimulus programs - is the support provided by governments to the financial sector with a view to preventing a breakdown of the financial system.

The key objectives of these measures were i.) to contain and reverse the stress in financial markets; ii.) to cleanse banks' balance sheets of impaired assets, and iii.) to recapitalize* and restructure viable but undercapitalised financial institutions, and resolve non-viable ones. Among the major forms of support that have been granted to the financial sector, we note guarantees, liquidity provision and other support by central banks, central bank support provided with treasury backing, asset purchases and lending by the treasury, and capital injections. These measures differ widely with regard to characteristics such as the degree of distortions to markets, the market impact of their unwinding, the contingency for fiscal costs, and whether additional transactions are required for their unwinding - to name only a $\mathrm{few}^{30}$. Whereas this Chapter focuses on fiscal aspects of this support, the emergency measures are closely related to the monetary policy interventions discussed in the next chapter.

Figure 9 shows the total amount of government support to the banking system in percent of 2008 GDP (see columns, left axis) and the required upfront government financing in \% of 2008 GDP (see dots, right axis). Figure 9 makes it clear that countries have been affected by the financial crisis to differing extents, and that they have chosen different instruments (in particular with regard to the upfront financing needs) to tackle the problems. Ireland, for instance, has provided total support to its banking industry in the amount of $266.4 \%$ of 2008 GDP; however, since most of this support

\footnotetext{
${ }^{30}$ For a more detailed account and discussion of market interventions during the financial crisis, as well as references to recent studies in this respect, see INTERNATIONAL Monetary Fund (IMF) (ed.), Global Financial Stability Report-Navigating the Financial Challenges Ahead, IMF, Washington, D.C., October 2009. Available at http://www. imf.org/external/pubs/ft/gfsr/2009/02/pdf/text.pdf, Chapter 3.
} 
has taken the form of guarantees (261\% of GDP), the upfront financing needs amount to 'only' $5.4 \%$ of GDP. In this respect, the situation in Ireland differs from the situation in the UK, the country providing the second highest headline support in terms of 2008 GDP (81.6\%). Although total support is much lower in the U.K. than in Ireland, upfront financing needs in the UK are much higher, at $18.9 \%$ of 2008 GDP, due to a more intense use of measures in the categories 'asset purchases and lending by the treasury' and 'central bank support provided with treasury backing'. As Figure 9 also makes clear, advanced economies had to support their financial sectors to a much higher extent than developing and emerging economies.

Figure 9 - Headline Support for the Financial Sector and Upfront Financing Needs (as of 19 May 2009; in \% of GDP)

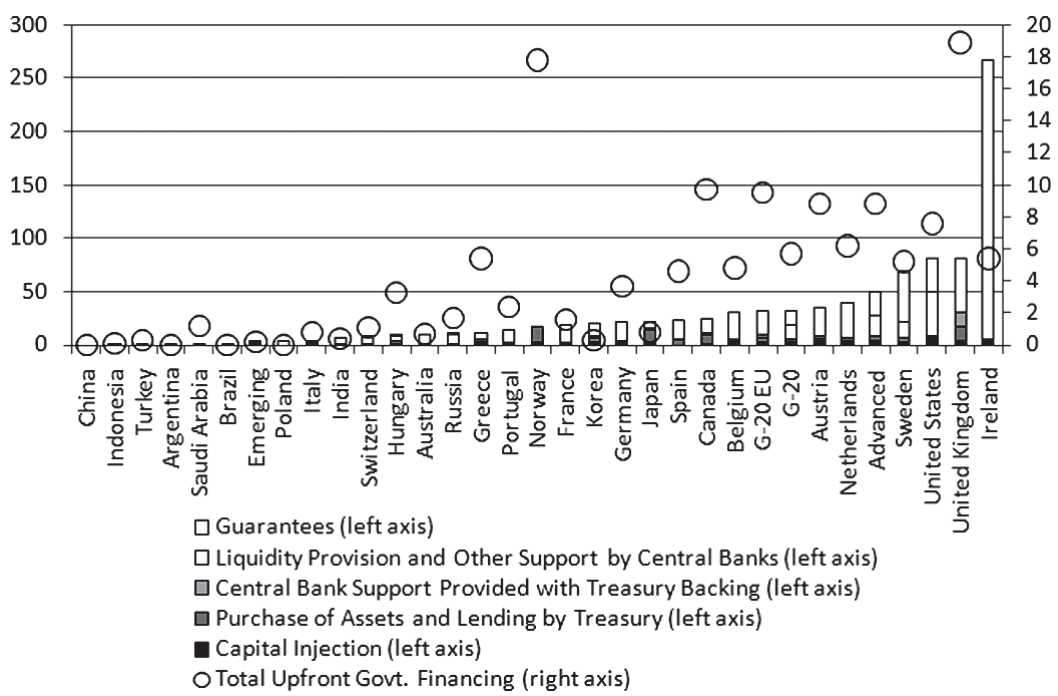

Graph: Thomas A. Zimmermann; data source: International Monetary Fund (IMF) ed. (2009): Fiscal Implications of the Global Economic and Financial Crisis; IMF Staff position note SPN/09/13, 9 June 2009, Table 2.1, pp. 7f.

\subsection{Protectionist effects of fiscal policy measures}

According to a joint report of the OECD, WTO and UNCTAD (2009), eleven $\mathrm{G}-20$ countries $^{31}$ and the European Union took emergency measures with

${ }^{31}$ Australia, Canada, France, Germany, India, Italy, Japan, the Republic of Korea, the Russian Federation, the United Kingdom and the United States. 
a potential of restricting or distorting worldwide capital movements. The public expenditure commitments related to these programmes amount to 3 trillion USD. As the report notes, «the sheer size of these measures and their potential effects on competitive conditions (e.g. on firm entry and exit) in globalised sectors such as finance and automobiles create a strong presumption that they influence worldwide capital flows. Moreover, akin to subsidies, emergency measures may effectively create advantages for domestic sectors and put foreign players at a disadvantage».

More generally, the government support scheme may be a source of widespread protectionist elements: whereas some crisis protection schemes are de iure open to foreign-controlled companies (e.g. car scrapping schemes applying for domestically produced and imported cars alike), others are not. Often, it is also quite difficult to draw the line. Discussions have arisen, for instance, with regard to the French rescue package for Renault (where the French government allegedly make the subsidies dependent upon production being maintained in France) or in the German government's preference for a sale of OpeL (a subsidiary of U.S. controlled General Motors) to a consortium that would have allegedly maintained jobs in Germany rather than other Opel production sites.

With regard to support schemes for financial institutions as well, some instances of protectionist behaviour have become manifest. The government programmes in favour of banks have often brought obligations to increase lending to domestic businesses, according to a report by the INTERNATIONAL INSTITUTE OF FINANCE (2009) which is quoted in a study by the WTO (2009a): According to the IIF, the UK Government has required banks receiving public assistance to agree to domestic lending growth targets. French banks that tap government assistance have allegedly pledged to increase domestic lending by $3-4$ per cent annually, while ING, a Dutch bank, which has received government assistance, has reportedly promised to extend € 25 billion in loans to Dutch businesses and consumers. According to the same source, Austria requires assisted banks to strive to make available 200 per cent of (government) participation capital to provide credit to Austrian businesses. Similar requirements are apparently in place in Greece. In addition, while there is no explicit requirement, the US government appears to have asked TARP ${ }^{32}$ - assisted banks to report regularly on the growth of domestic lending.

Beyond the protectionist potential of discretionary spending, certain beggar-thy-neighbour behaviour can also be noted on the revenue side of fiscal policy, i.e. in tax policies. A noteworthy feature is the

${ }^{32}$ The TARP, or Troubled-Asset Relief Programme, is a programme of the U.S. government to purchase troubled assets (e.g. securities based on residential or commercial mortgages) from financial institutions with a view to strengthening its financial sector. 
success of the G-20 countries in establishing an international tax cartel with the active support of the OECD. It has become manifest in actions against so-called 'tax havens' (mainly through threats of blacklisting such countries) with a view to hollowing out bank customer secrecy on the international level through forced acceptance of the OECD standard on information exchange in double taxation treaties. Whereas the stated goal of these efforts is to secure tax compliance and tax revenue, one may reasonably assume that a more hidden, protectionist agenda is also at play: the support of G-20 governments for their own financial places (e.g. London) in the highly competitive quest for internationally mobile capital.

Discussions about the use of stolen bank customer data by fiscal authorities, and its international political repercussions, are another indicator of the heated climate regarding tax issues. The same holds for Italian raids on Swiss bank branches in Italy and the rhetoric of Italian Finance Minister Tremonti against foreign bank deposits, and against the financial centre of Lugano (Switzerland) more specifically. Other tax initiatives around the globe (e.g. the 'Steuerhinterziehungsbekämpfungsgesetz' in Germany, or the 'Levin Bill' in the U.S.) seek to fight tax evasion, often with a protectionist element. Taken together, all these initiatives send a strong signal about the increasingly squalid character of large countries' international tax policies - with potentially regrettable consequences for the protection of economic privacy rights (and perhaps even for property rights in the longer run).

Other currently discussed tax projects do not have a protectionist bias, at least not prima facie. But constitute nevertheless heavy interventions, e.g. the 'bonus tax' discussed in the U.K. and France or the bank tax proposed by the Овама Administration in January 2010.

\section{Monetary policies: different forms of policy reaction}

Monetary policy has been another key area of reaction to the current financial and economic crisis. Central banks have made use of a wide array of policies. The most important instruments include interest rate cuts, so-called 'unconventional measures' or 'quantitative easing' (including various support measures), and interventions on foreign exchange markets. 
Along with fiscal policy, monetary policy has arguably been the most important area of economic interventionism, with the potentially deepest impact on the economy in the longer term.

\subsection{Interest rate cuts}

Virtually all major central banks have reacted to the crisis with massive interest rate cuts. The average of the short-term* policy rates of the U.S. Federal Reserve (Fed), the European Central Bank (ECB), the Bank of England (BoE), the Bank of Japan (BoJ) and the People's Bank of China (PBC) has declined by more than 3 percentage points, i.e. from $4.27 \%$ p.a. in June 2007 to 1.17\% p.a. since May 2009 (data until October 2009). In the United Kingdom, for instance, the currently applied rate of $0.5 \%$ is historically the lowest rate ever since the Bank of England was established in 1694 (see Figure 10).

Figure 10 - Interest rates (Short-term policy rates, in \% per annum, 2000-2009)

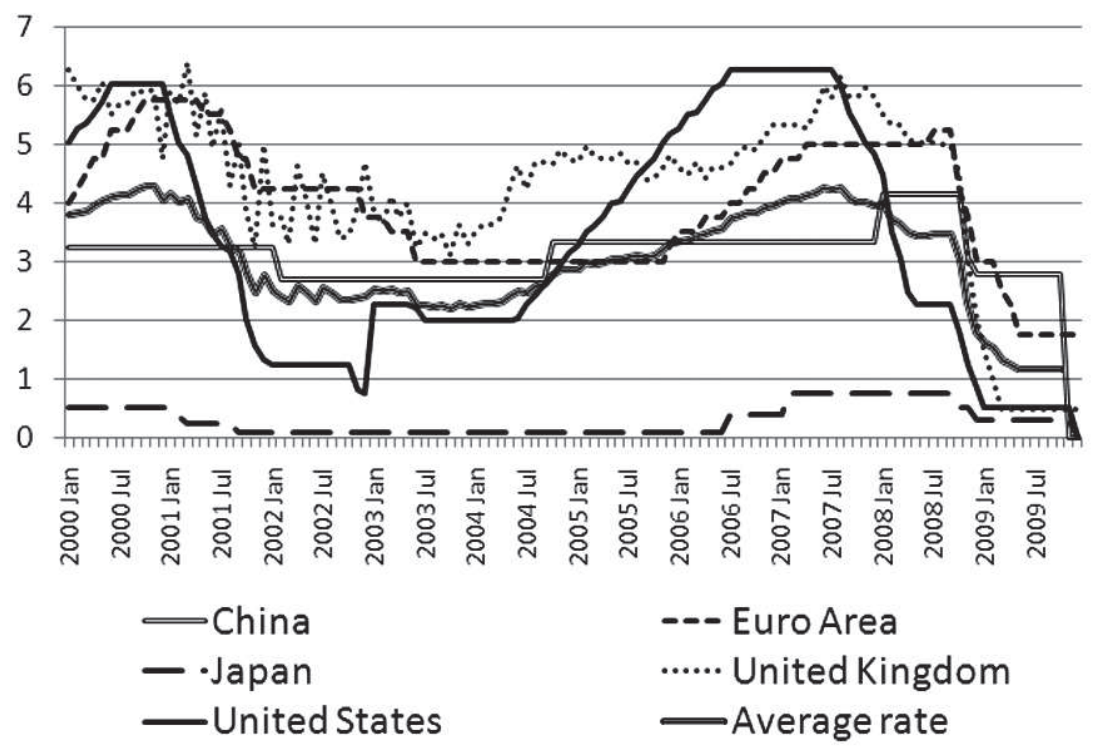

Graph by Thomas A. Zimmermann; Data source: International Monetary Fund (IMF) / International Financial Statistics (IFS); provided through Principal Global Indicators; http://www.principalglobalindiactors.org 


\subsection{Quantitative easing}

With rates having reached such low levels, the scope for further rate cuts has mostly been exhausted. Central banks have therefore engaged in so-called measures of 'quantitative easing' in order to further prop up credit markets and pump liquidity into the system. By engaging in such practices, they also contributed - at least for the time being - to keeping long-term interest rates down. Quantitative easing has taken on various forms; the most important instruments are purchases of government and corporate bonds as well as other securities.

Through these purchases, central banks supported the expansionary fiscal policies of governments and their deficit-spending efforts with a view to safeguarding the stability of financial systems and to upholding activity levels in their economies. By pumping enormous amounts of liquidity into the system, they have also sustained asset prices with a view to preventing the balances of banks, but also private households and other institutions (e.g. pension funds) from eroding. In doing so, they have managed to contain deflationary trends and to keep inflation expectations stable - at least for the time being.

Figure 11 - Expansion of Central Bank balance sheets in major economies

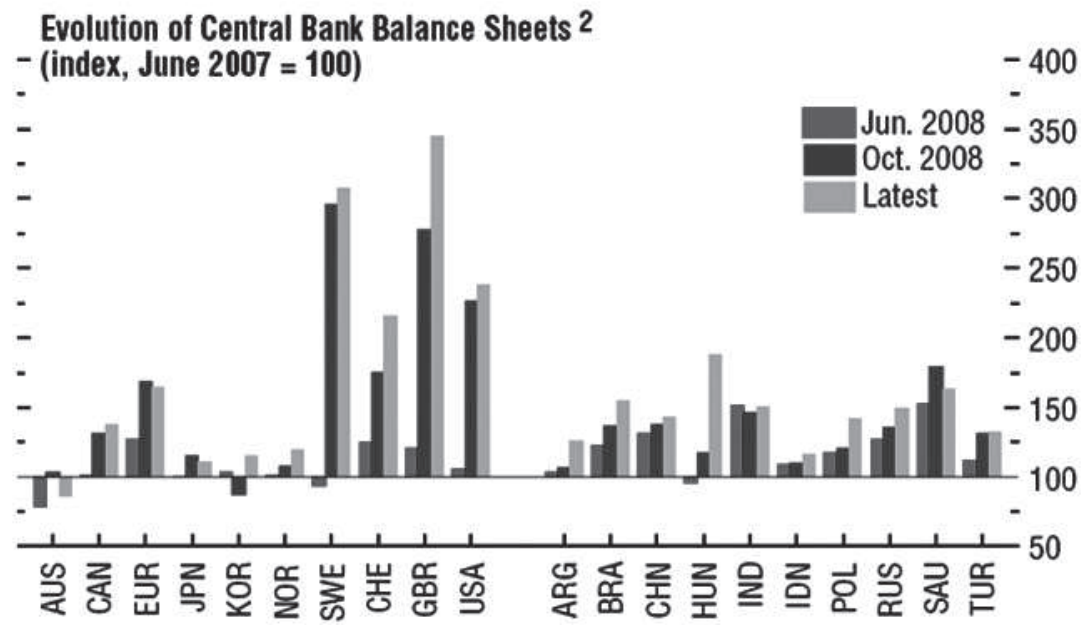

Source: IMF World Economic Outlook, October 2009; p. 28; http://www.imf.org

The proportions of these central bank interventions are unprecedented. The balance sheets of central banks have expanded massively. 
According to IMF data, the balance sheet of the Bank of England more than tripled between June 2007 and 2009. Other central banks with a considerable increase of their balance sheets are the Swedish Riksbank, the Swiss National Bank, and the U.S. Fed. As far as the ECB and the Bank of Canada are concerned, their balance sheets have increased rather moderately in relation to their previous levels - as did the bank balance sheets of most emerging and developing countries (see Figure 11).

An impressive reflection of this quantitative easing is the historic expansion of the adjusted monetary base in the United States. Figure 12 tracks this indicator for roughly the last one hundred years and shows the uniqueness of the $2008 / 2009$ policy actions.

Figure 12 - Expansion of the adjusted monetary base in the United States, 1918-2009, in billions of U.S. Dollars

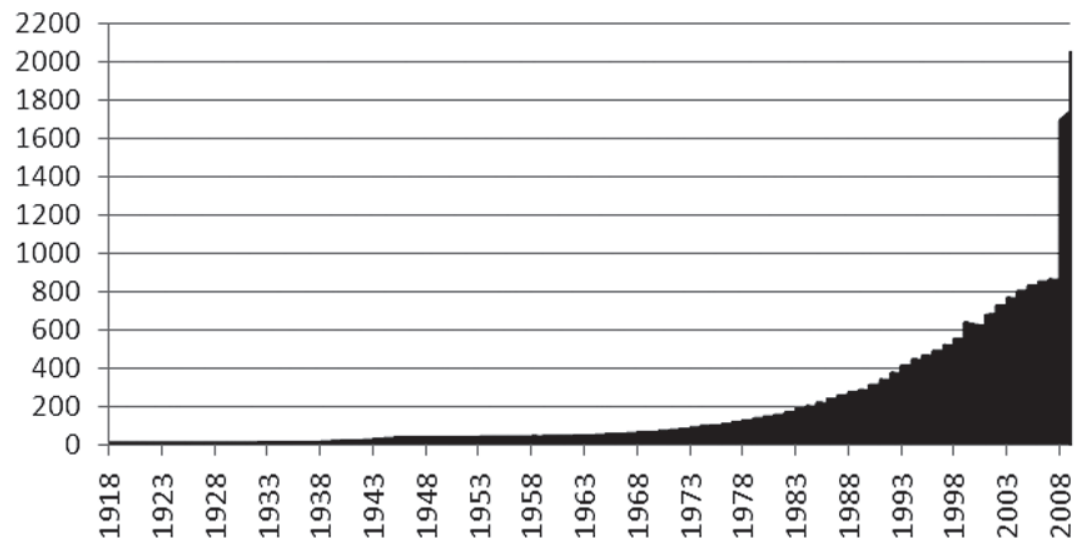

U.S. Adjusted Monetary Base (bn. USD, 1 January 1918 - 1 November 2009)

Graph by Thomas A. Zimmermann; Data source: Federal Reserve Bank of St. Louis: Data downloaded on 6 January 2010; Series AMBNS, St. Louis Adjusted Monetary Base; http://research.stlouisfed.org/fred2/series/ AMBNS? cid=124.

Further measures include adjusted reserve requirements, longer funding terms, more frequent auctions and/or higher credit lines. They also include an enhancing of the function of central banks as the lender of last resort through a broader set of eligible institutions, wider collateral rules and/or broader definitions of eligible collateral. In addition, central banks have also made use of their capacity as foreign 
exchange lenders of last resorts - i.e. by establishing foreign exchange swap lines with other central banks or forex repos ${ }^{33}$.

Finally, the role of the International Monetary Fund (IMF) and its greatly expanded crisis-related programs and lending activities could also be mentioned in this context ${ }^{34}$.

\subsection{Exchange rate interventions}

In addition to interest rates cuts and quantitative easing, some monetary authorities have also made use of interventions on foreign exchange markets.

A country that is regularly accused of manipulating its exchange rate is China. In fact, the Chinese central bank had never allowed its currency, the Yuan/Renminbi, to float freely against the US-Dollar. The chronically high trade surpluses of China (in combination with a deep trade deficit in the US) and the massive accumulation of reserves are a reflection of the macro-economic imbalances that allegedly were (and still are) among the facets of this crisis. After having kept its exchange rate stable to the U.S. Dollar throughout the late nineties and until 2005 at roughly $0.12 \mathrm{USD} / \mathrm{CNY}$ (or $8.28 \mathrm{CNY/USD),} \mathrm{China}$ accepted a gradual appreciation of the Yuan/Renminbi against the U.S. Dollar between 2005 and 2008 until an exchange rate of roughly $0.146 \mathrm{USD} / \mathrm{CNY}$ (or $6.8 \mathrm{CNY/USD)}$ had been reached. However, since summer 2008, the authorities have again kept their exchange rate fairly stable against the USD at this level (see Graph 13). Research published by the Peterson Institute for International Economics in 2009 finds that the Yuan/Renminbi was undervalued by $21 \%{ }^{35}$.

${ }^{33}$ For an overview of these measures, see also Table 3.1 in IMF, Global Financial Stability Report 2009, Chapter 3, p. 4. For the context of fiscal policy measures to stabilise financial markets, see also Section 4.3. On 'unconventional measures' in general, see C. BORIO - P. Disyatat, Unconvential monetary policies - An Appraisal, BIS Working Papers, 292, 2009. Available at http://www.bis.org/publ/work292.pdf and Bank for International Settlements (BIS) (ed.) 79th Annual Report, BIS, Basel 29 June 2009. Available at http://www.bis.org/publ/arpdf/ar2009e.pdf, Chapter VI.

${ }_{34}$ See International Monetary Fund (IMF) (ed.), Review of Recent Crisis Programs, IMF, Washington, D.C., 14 September 2009. Available at http://www.imf.org/exter$\mathrm{nal} / \mathrm{np} / \mathrm{pp} / \mathrm{eng} / 2009 / 091409 . p d f$ for details.

35 See W.R. Cline. - J. Williamson, Estimates of Fundamental Equilibrium Exchange Rates, «Policy Brief» No. PB 09-10, Peterson Institute for International Economics, Washington, D.C. June 2009. Available at http://www.piie.com/publications/pb/ pb09-10.pdf, p. 7 and Table 2. 
Figure 13 - Exchange rate Chinese Yuan/Renminbi in US Dollars, 1995-2009

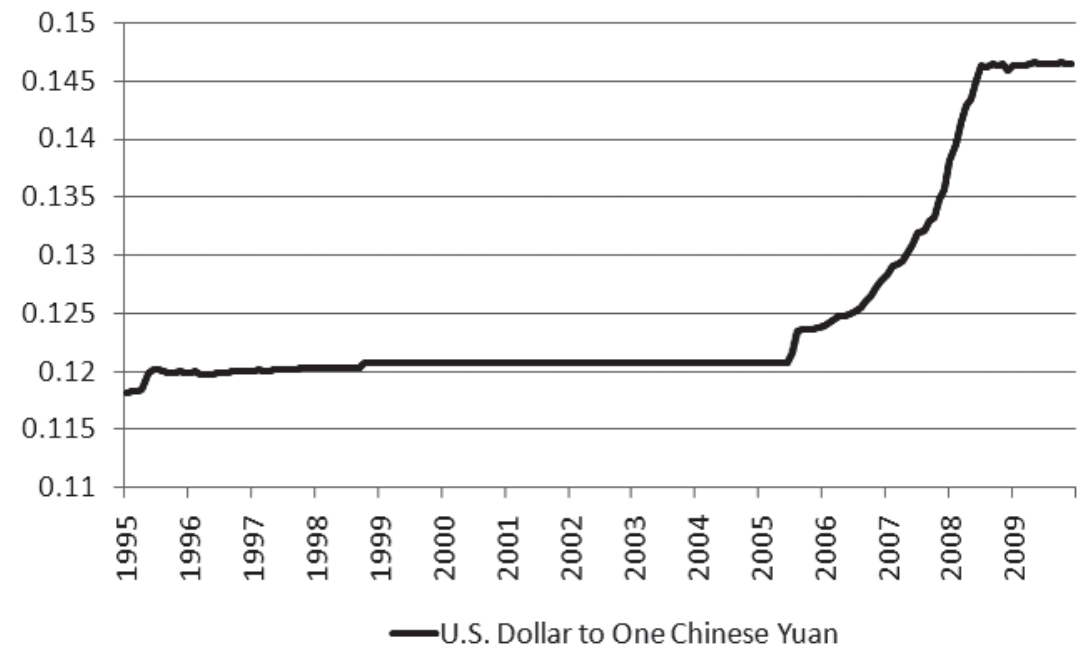

Graph by Thomas A. Zimmermann; Data source: Federal Reserve Bank of St. Louis: Data downloaded on 6 January 2010; available at http://research. stlouisfed.org/ fred2/categories/15

Another example of a country that has recently targeted its exchange rate is Switzerland. In its monetary policy assessment on 12 March 2009, the Swiss National Bank (SNB) stated that «[d]ecisive action [...] to forcefully relax monetary conditions» was called for, and that it would «act to prevent any further appreciation of the Swiss franc against the euro. To this end, [the Swiss National Bank] will increase liquidity substantially by engaging in additional repo operations, buying Swiss franc bonds issued by private sector borrowers and purchasing foreign currency on the foreign exchange markets».

The announcement of 12 March 2009 was immediately felt on foreign exchange markets: The Euro rose from below $1.47 \mathrm{CHF}$ to close to $1.54 \mathrm{CHF}$ (interbank rate; see Figure 14). Amidst occasional rumours about SNB interventions and the markets' hypothesis that the Swiss National Bank would defend an exchange rate of $1.50 \mathrm{CHF} / \mathrm{EUR}$, the Euro stayed above this 'line in the sand' through most of the year. However, the Franc began to appreciate again after the SNB had slightly changed the wording in its monetary assessment of 10 December 2009. In this assessment, the SNB merely stated that it would «act decisively to prevent any excessive appreciation of the Swiss franc against the euro». Markets reportedly interpreted this softening of language ("prevent any 
excessive appreciation' versus 'prevent any further appreciation') as a softening of the SNB stance. The Euro closed the third week of 2010 at an interbank exchange rate of slightly more than $1.47 \mathrm{CHF} / \mathrm{EUR}$.

Figure 14 - Exchange Rate CHF/EUR, 1 January 2009 - 9 January 2010 (in Swiss Francs per 1 Euro)

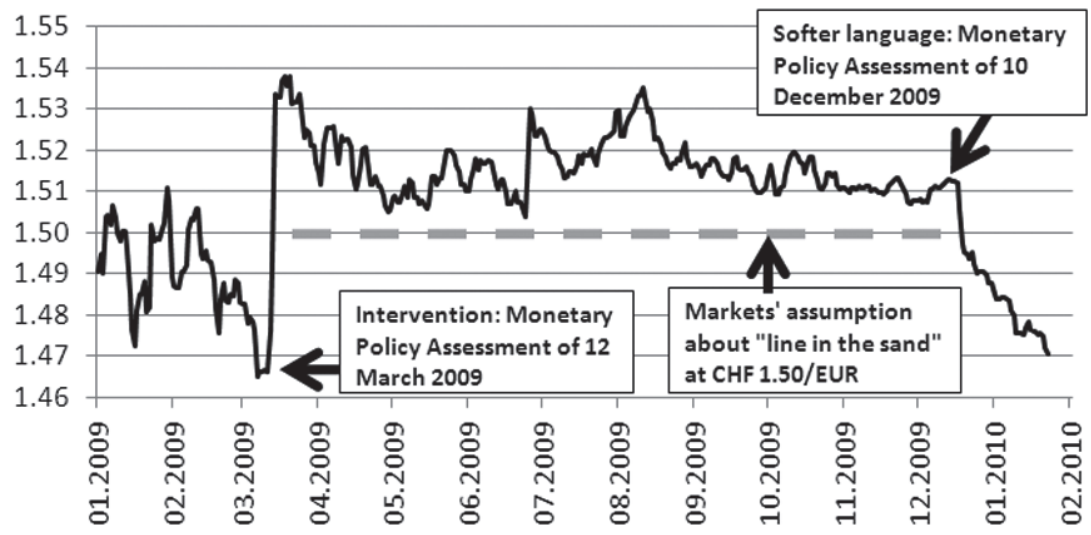

— Swiss Franc to one Euro

Graph by Thomas A. Zimmermann; Data source: OANDA website, historical exchange rates (interbank rates), http://www.oanda.com/lang/de/currency/ historical-rates; Swiss National Bank (2009), and Swiss National Bank (2009a)

The interventions on exchange markets by China in particular have been criticised by both academic observers and policymakers. The reluctance of the authorities to let the Yuan/Renminbi float freely is a major irritant in the U.S. and is considered an impediment on the way towards the removal of international macroeconomic imbalances. In combination with the weaker U.S. Dollar, the fixed Yuan/Renminbi-Dollar exchange rates have become onerous for those currency areas that let their currencies float freely against the USD, such as the Euro.

Bergsten (2009) - as one of the fiercest critics of China's exchange rate policies - has also criticised Switzerland, stating that «its aggressive, although admirably transparent, intervention in the currency markets has served to weaken the exchange rate of the Swiss Franc despite the country's huge current account surpluses». He argues that «over the next few years, as more countries seek to export their way out of the current crisis and build larger war chests of foreign exchange to self-insure 
against future exigencies, there could be more, and more serious, examples of such neomercantilism».

Apart from the criticism voiced by Bergsten, criticism of the Swiss policies has, however, remained fairly moderate. Indeed, there are several noteworthy differences between the Chinese and the Swiss case: i.) Switzerland, unlike China, has an open capital market and the Swiss franc, unlike the Chinese Yuan Renminbi, is a freely convertible currency; ii.) The Swiss franc, unlike the Chinese Yuan/Renminbi, has the character of a safe haven currency which makes it vulnerable to appreciation in situations of international monetary turmoil; iii.) Switzerland is a far smaller player in the world economy than China, and is not the root cause of comparable international imbalances; iv.) The SNB has, in preventing an uncontrolled appreciation of its currency, contributed considerably to financial stability in Eastern and Central Europe (e.g. Poland and Hungary) where a high share of mortgages and credits is denominated in Swiss francs. Finally, the SNB has recently softened its stance somewhat - unlike China which has so far insisted on pursuing its current exchange rate policy.

Apart from China and Switzerland, there are other countries that have recently taken action indirectly to ward off an appreciation of their respective currencies: for instance, Brazil has introduced a tax of $2 \%$ on foreign portfolio investments in Brazilian stocks and bonds to deter capital inflows. Taiwan has banned foreign inflows in time deposits. More Asian emerging markets have recently intervened to avoid appreciations of their currency and to deter massive capital inflows as interest rates remain on record lows in advanced economies. On 7 January 2010, the new Japanese Finance Minister, NАото Kan, said in his inaugural press conference that he would like the Japanese Yen to weaken 'a bit more' after it had already dropped 9\% from its 14-year high in November 2009. Markets reacted to this verbal intervention with the Yen losing value on currency markets.

\section{The return of interventionism: Main findings from the analysis}

\subsection{Trade policy: Increased protectionism, but no catastrophe so far}

The preceding chapters make it clear that governments have made frequent recourse to economic interventionism in their efforts to ward off the effects of the economic crisis, in particular with regard to avoiding a financial meltdown and rising unemployment. 
The flurry of trade policy measures clearly shows a rise of protectionism, particularly in mature industries suffering overcapacities as well as in financial services. At the same time, there is little momentum towards trade liberalisation - particularly on the multilateral level. Both findings suggest that we will have to live with a higher level of global protectionism for some time to come. The good news, however, is that protectionism has not yet increased to an extent which would have led to a 1930s style breakdown of world trade or to escalating, large-scale trade wars. It should be noted, however, that a large number of protectionist measures are still in the pipeline. Protectionist measures take some time to be designed and to be put into effect. Moreover, in case the world economy were not able to sustain its recovery (e.g. in the case of a so-called 'double dip recession'), protectionist pressures might well increase further. In sum, it is therefore too early for a final assessment.

\subsection{Investment policy: A relatively comforting picture}

The analysis of investment policy measures has brought overall comforting results: although the trend towards investment liberalisation has lost some momentum in the $2^{\text {nd }}$ half of the last decade, the measures liberalising international investment still outnumber the restrictive ones. An exception to this fairly positive picture is Latin America where hostile attitudes towards FDI and foreign multinationals are on the rise. Another edifying result is that the financial and economic crisis has not specifically pushed investment policy towards protectionism. By contrast to its effects on trade policy, the crisis even seems to have pushed some countries into a more liberal stance towards international investment. A good example in case is the attitude towards Sovereign Wealth Funds (SWFs).

\subsection{Fiscal Policy: An alarming picture}

Despite the number of the trade and investment policy measures taken during the crisis, the weight of interventions in these areas is dwarfed by the actions taken in fiscal and monetary policy. In fiscal policy, enormous amounts of money have been spent to stimulate the economy and to save ailing banks. Given the sheer size of government assistance during this crisis (as measured as a percentage of GDP), the enormous potential of stimulus and emergency measures as sources of economic distortions becomes apparent. Several risks emerge. 


\subsubsection{Microeconomic threats: The risk of state failure}

Through the emergency measures taken, governments have become deeply involved in the management of banks and other companies. This raises challenges with regard to potential conflicts of interest inside the government - e.g. between the government's primary role as a regulator versus its newly acquired role as a banker or industrial entrepreneur (e.g. in granting credits, in enforcing competition policy etc. $)^{36}$. This conflict of roles poses serious threats to sound economic governance.

Political pressures against a rapid divestment and in favour of perpetuating the political control of the acquired businesses will increase, in particular from the interventionist and statist camps. The public (co-)ownership of firms will also pose challenges for the nondiscriminatory treatment of investors, including upon divestment. The discretion enjoyed in the negotiations and structuring of deals may lead to favouring certain firms over others, e.g. with a view to creating 'national champions'.

\subsubsection{Macro-economic consequences: An unsustainable debt burden}

The combined effects of automatic stabilizers (i.e. reduced tax income and/or increased social security spending), stimulus measures, and emergency support have a deep impact on government finances. In addition, risks to government finances through the provision of guarantees (e.g. in the case of Ireland, where such guarantees amount to $261 \%$ of GDP) have increased sharply.

The degradation of government finances as a consequence of the crisis is therefore of little surprise. This degradation is much worse in advanced countries with their heavily affected financial sectors than in emerging markets. Figure 15 illustrates the differing IMF projections

\footnotetext{
${ }^{36}$ An analysis of the effect of government ownership of banks on bank lending is included P. SAPIENZA, The effects of government ownership on bank lending, "Journal of Financial Economics», 72 (2004), 2, pp. 357-384. Available at http://dx.doi. org/10.1016/j.jfineco.2002.10.002. His findings (p. 359) «support the political view of [state-owned enterprises] and suggest that state-owned banks serve as a mechanism to supply political patronage». The findings also «show that government ownership of banks has distorting effects on the financial allocation of resources». See also R. La Porta - F. Lopez-De-Silanes - A. Shleifer, Government Ownership of Banks, Harvard University, SSRN, Cambridge, MA, 2000 (available at http:/ / papers.ssrn.com/sol3/ papers.cfm?abstract_id=236434) on the negative effects of a politicised allocation of financial resources on productivity and growth. On the issue of state versus private ownership in general, see A. SHLEIfER, State versus Private Ownership, «Journal of Economic Perspectives», 12 (1998), 4, pp. 133-150. Available at http://www.jstor. org/stable/2646898?origin=JSTOR-pdf.
} 
for public finances in advanced G-20 countries and in emerging G-20 countries. Despite a presumed moderation of the deficits after 2009, the overall government debt level is expected to increase to beyond $110 \%$ of GDP by 2014 in advanced countries (Figure 15a). Compare this to the projections of the IMF for emerging G-20 countries which, thanks to much smaller deficits, should be able to reduce overall government debt to roughly $35 \%$ by 2014 - a third of the then level in advanced countries.

Figure 15 - G-20 Countries: Outlook for Public Finances

a) Advanced G-20 countries

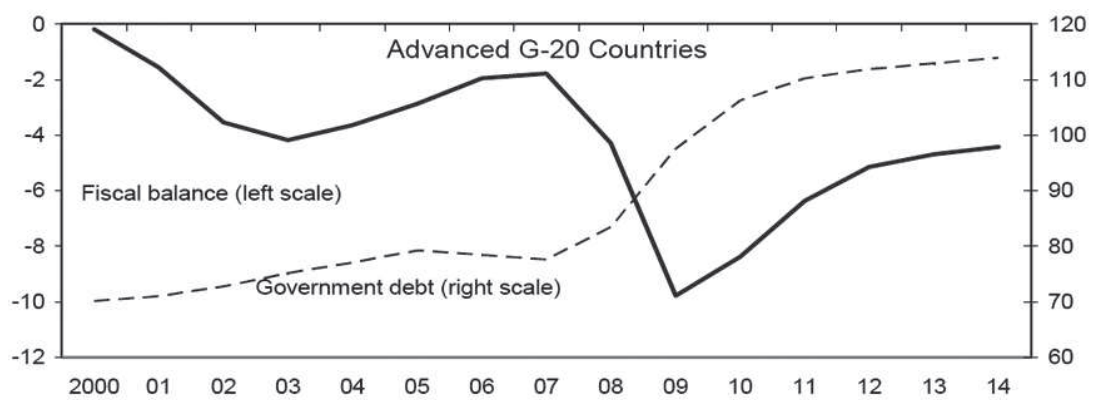

b) Emerging market G-20 countries

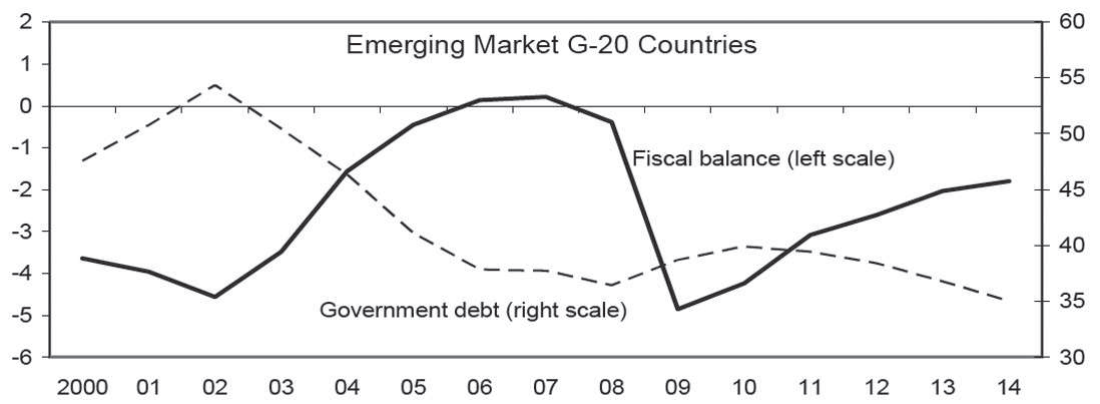

Source: IMF (2009b), p. 23.

Whereas the projected evolution of government finances until 2014 alone would already be sufficient reason for concern, the picture gets even more worrisome if we consider the IMF forecast for the next four decades. Until 2050, the IMF currently expects fairly steep increases in the share of government debt into the sphere of $300 \%$ of GDP for 
advanced countries (see Figure 16), with population ageing and demographic developments taking their toll.

Figure 16 - Advanced G-20 Countries: Government Debt

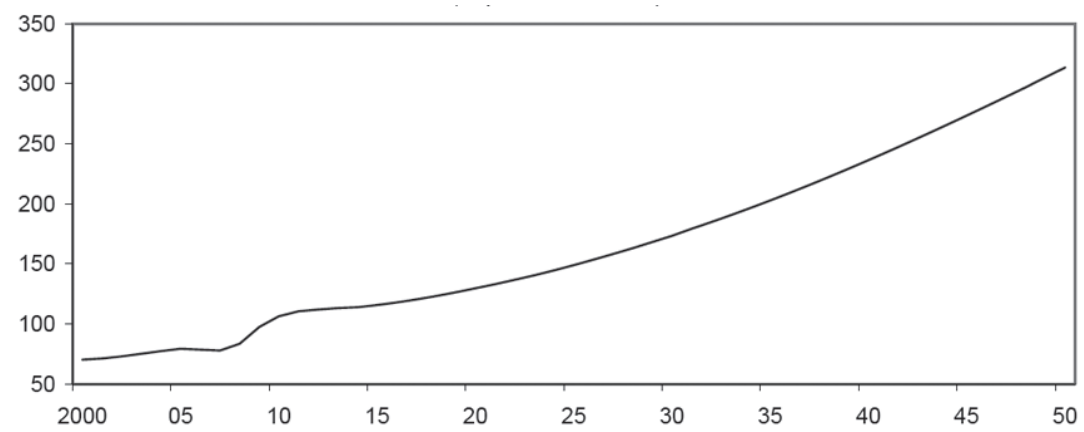

Source: IMF (2009b), p. 39.

It is difficult to perceive how the ageing (and partially shrinking) populations in the developed economies will ever be able to stabilise, let alone repay, this ballooning debt. Rather, social security systems with insufficient coverage and/or inadequate investments (e.g. into public debt which needs to be serviced by the insured population itself), as well as existing private debts, could add to increasing serfdom of individuals.

Since interest rates may be expected to rise again from their historically low levels (in particular as far as risk premia and inflation premia are concerned, in the light of the decreased creditworthiness of borrowers), this burden will likely become even more onerous. Whatever strategy will be chosen by governments to cope with this debt - massive tax increases, inflation, sweeping cuts in public services, or a combination of these - the adjustment process is likely to be painful and to gnaw at the prosperity of generations to come. In the light of the demographic decline, the saturation of markets and the magnitude of the debt issue, a comfortable way out, which would be built on a swift return of high growth rates, is not a realistic option. Nor is a miraculous increase of tax income through some Laffer curve effects from lower tax rates. 


\subsection{Monetary policy: Unknown risks in unknown territory}

Besides fiscal policy, monetary policy has been the major area of interventionism. As far as the interest rate reductions are concerned, these are quite commonplace as an instrument of monetary policy, and they are continuously used by monetary authorities in the conduct of their business. Their effects and side-effects on the economy are fairly straightforward. The interest rate reductions may be considered the least discretionary and the least discriminatory element in the monetary toolbox that was used during this crisis.

The same cannot be said for the unprecedented 'unconventional' measures that were taken by central banks during this crisis - in particular the 'quantitative easing' measures. Conventional wisdom would suggest that such an expansion of the monetary base will likely lead to massive inflation in the future. Critics of this assumption argue, however, that credit channels remain clogged for some time (due to the need of both financial institutions and a large number of private borrowers to restore their balance sheets) and that the output gap is too large for allowing inflation to rise. Nevertheless, the huge amounts of liquidity may sooner or later find their way into markets, if they are not mopped up in due time. They may increase the prices of certain real estate, stocks and tangible assets (e.g. raw materials) and trickle from there into other parts of the economy. It could also be argued that current price stability still owes much to the fairly wellanchored inflation expectations which, in turn, are built on the experience of the 'great moderation' in the last 25 years. If these expectations were to even gradually de-anchor, prices could develop more momentum.

More generally, the effect of monetary policies should not be considered in isolation but against the background of other areas of intervention, i.e. the massive fiscal expansion in particular. Fears that Western central banks and Western governments could collaborate in inflating at least some of the onerous debt burden away, seem fairly plausible. A possible indicator for future inflation expectations and for monetary instability is the gold price (see Figure 17), since gold is largely a 'monetary commodity' of limited industrial value. The willingness to hoard this non-interest bearing asset - which manifests itself in massive capital inflows into Gold ETFs (Exchange Traded Funds) and in the return of central banks as net buyers of the yellow metal - may also be interpreted as a loss of confidence in the willingness and/or ability of governments and central banks to restore macroeconomic stability ${ }^{37}$.

${ }^{37}$ On the role of gold as a hedge against macro-economic imprudence, see, for instance, the piece by A. Greenspan, Gold and Economic Freedom in A. RAND (ed.), 
Figure 17 - The Gold Price (2000-2009); USD/ounce; Daily London pm Gold Fixing

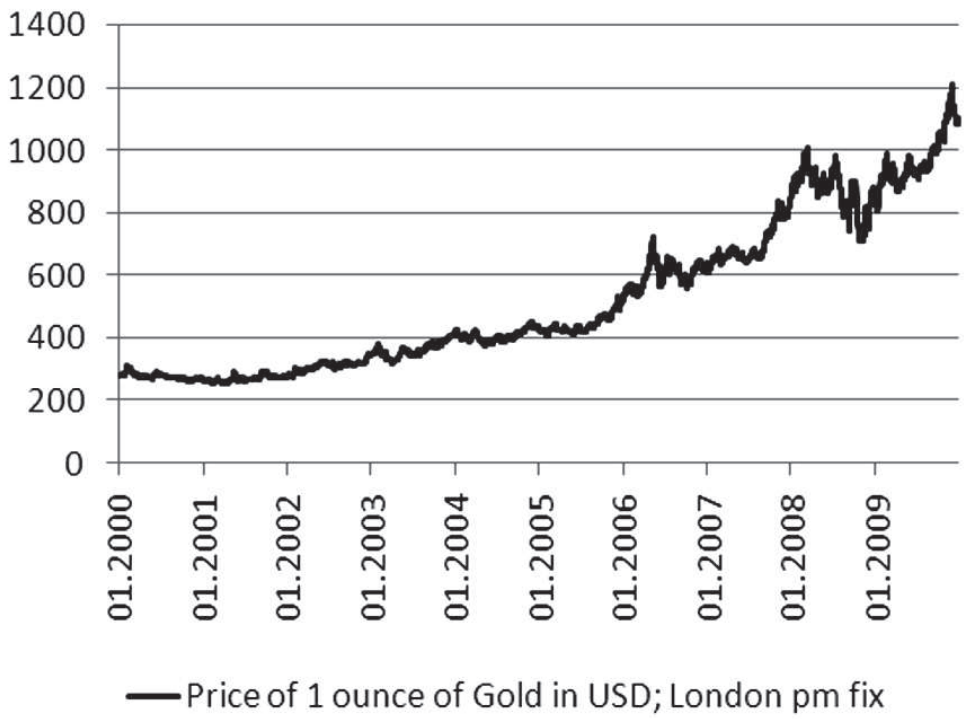

Graph by Thomas A. Zimmermann; Data source: World Gold Council website. http://www.gold.org/deliver.php?file=/value/stats/statistics/xls/web_daily.xls

Whereas low interest rates and quantitative easing can indirectly have protectionist effects (through depreciations of the currencies concerned), interventions on foreign exchange markets (and pegged exchange rates more generally) have a direct effect on trade flows. Distortions may be expected in particular from the pegging of the Chinese Yuan/Renminbi to the U.S. Dollar at a low exchange rate - in light of the estimated extent of the undervaluation on the one hand, and in light of China's weight in world trade on the other. This likely perpetuates international imbalances.

\subsection{Overall assessment: Economic interventionism has returned}

In an overall assessment of the policy areas surveyed in this paper, it may be said that governments and central banks around the globe have made use of a wide array of tools to fight against the financial and economic

Capitalism - The Unknown Ideal, Signet, The New American Library Inc., New York 1967, pp. 96-101. 
crisis. Whereas these measures may have helped to contain the slump in economic activity as well as deflationary threats, their cumulative effect has also been a steep increase in the amount of interventionism in the economy.

The Schumpeterian concept of 'creative destruction' and the subsequent structural change have not been allowed to proceed at the pace dictated by the markets. Governments around the globe have replaced private demand through government demand or through incentives steering demand into specific sectors affected by the crisis. Ultimately, such taxfinanced or debt-financed stimulus schemes withdraw sovereignty from consumers and prevent the necessary capacity adjustments.

The artificial conservation of overcapacities and hypertrophic economic activity is unsustainable - from an economic, financial, social and ecological point of view. The measures taken, although successful in the short run, are associated with costs and risks in the medium to long term. Gravitation cannot be conned in the long run.

In the medium term, rising bond yields, interest rates and increased inflation may already begin to materialise before the economic and financial crisis is fully over. The currently steep yield curve is a warning sign. Increasing costs of debt service may enforce painful spending cuts and a weaker public service in the more indebted countries, reducing prosperity and the quality of life. At the same time, protectionist distortions and higher taxation will be millstones around advanced economies' neck, further hampering their limited growth perspectives. Additional difficulties - such as increasing resource prices resulting from stronger demand in emerging market economies and the expanded monetary base - may add to the challenges for policymakers in the North.

In the longer term, the crisis may act as a catalyst for the global shift that is already taking place. Huge public debts and the political dominance of an ageing, risk-averse population in the North will fuel internal and international distribution conflicts. These are set to weaken the position of advanced countries in economic, political, and - ultimately - military terms. This erosion may proceed at a faster or slower pace, depending upon many factors. One crucial factor will be the extent to which the U.S. Dollar will be able to reaffirm itself as the world's leading currency, conveying a vital role and considerable benefits of seignorage to the United States $^{38}$.

From a liberal economist's point of view, one of the regrettable aspects is that the current problems will be attributed rather to allegedly 'neo-liber-

${ }^{38}$ For a recently published overview on the role of the U.S. Dollar, see WTO, Overview of Developments, 2009, Part B, Chapter C. 
al' economic policies of the past than to past interventions of governments and central banks. It is easily forgotten that the current financial crisis was first and foremost the result of an overly lax U.S. monetary policy and the government-sponsored mortgage frenzy, i.e. a de-facto period of Keynesianism in the aftermath of 9-11 and the bursting of the technology bubble in 2000/2001. By heavily engaging in economic interventionism once more, governments and central banks are now repeating the same kind of actions, albeit at a larger scale, that led to this crisis in the first place.

\section{Policy options}

In this last chapter of the paper, we will discuss some policy options to address the problem of rising interventionism and to return to more market-oriented policies. In the light of the broad scope of this paper, we will present an overview of policy approaches rather than a detailed discussion of each and every issue.

\subsection{Trade policy: Monitoring, dispute settlement and negotiations}

Monitoring: In the light of the manifold pressures towards protectionist measures, monitoring efforts must continue. They ensure the transparency of trade policy actions, thereby also creating normative pressure against protectionism. Beyond the monitoring efforts of international organisations such as the WTO, private efforts from initiatives such as Global Trade Alert (GTA) are most welcome because they are more independent in their analysis than the 'member-driven' WTO.

Dispute settlement: Governments should make active use of the dispute settlement mechanisms in the WTO and under regional trade agreements by challenging their trade partners' violations of trade rules. Export-oriented business and trade associations should lobby with their governments for a defence of their foreign commercial interest in these fora. Governments occasionally tend to shy away from bringing complaints because these may be considered unfriendly diplomatic actions and provoke counter-complaints from the defendants ${ }^{39}$. From an economic perspective, however, an active use of dispute settlement mechanisms

\footnotetext{
${ }^{39}$ See Zimmermann, Negotiating the Review of the WTO Dispute Settlement Understanding, Cameron May, London 2006 (available at http://www.zimmermann -thomas.de/ publikationen/zimmermann_2006_book_dsu.pdf) with further references.
} 
is desirable - and a far better option than a cartelistic agreement between governments not to challenge each other's violations any more.

On-going WTO negotiations: Even if the chances for an agreement are dim, WTO Members should carry on in their efforts to negotiate on a Doha package, pursuing reasonable results. On-going negotiations about further liberalisation reduce the risk of a protectionist backlash. This requires, however, a more active participation from several major parties. In particular, the United States should finally make its strategy for the Doha Round clear. Moreover, emerging economies should assume greater responsibility for the system and leave their conceptions of asymmetrical concessions behind. The private sector could also engage more actively, pressing lawmakers and governments towards more ambition in trade negotiations.

FTA negotiations: Although Free-Trade Agreements are only a second best solution for international trade liberalisation (with multilateral agreements being the first best option), they provide an additional safety net for open trade and allow to lock-in concessions, particularly in times where protectionist pressures increase. Countries should therefore continue their efforts to strike more free-trade deals while making sure that such deals have the least possible trade-diverting effect and do not create new obstacles for multilateral liberalisation. The respect of the rules laid down in Art. XXIV GATT ${ }^{40}$, the use of provisions that are supportive of the multilateral trading system, and the definition of liberal rules of origin (in general, and for the cumulation of value-added) are required.

Other policy options: Other possible policy options include self-commitments of governments not to introduce protectionist measures, and to phase out existing measures (e.g. anti-dumping duties, CVDs, safeguards, etc.) as soon as possible. In general, unilateral steps towards trade liberalisation host much economic potential for the liberalising country. An example in case is the unilateral introduction of the Cassis de Dijon principle in Switzerland which amounts to a unilateral removal of technical barriers to trade. Another possible (and, in fact, long overdue) step towards unilateral liberalisation is the elimination of nuisance duties (i.e. duties of below 2\%) or low duties in general. This step would bear only relatively small political costs but it could considerably facilitate traders' business if applied to broadly defined product categories. Nuisance duties cause high administrative costs without yielding much government revenue and without offering much bargaining value in trade negotiations.

\footnotetext{
${ }^{40}$ Art. XXIV GATT establishes basic principles which free-trade agreements should fulfill in order to be compatible with multilateral trade rules. These include the prohibition of raising barriers to trade with non-parties, notification requirements as well as rules for the scope of FTAs and the timing of their implementation.
} 
Long run options: In the longer run, more fundamental and more creative measures will be required to maintain the multilateral trading system as a productive instrument for trade liberalisation. These might include a new approach towards negotiations (e.g. plurilateral negotiations or new rules for decision-taking), as the current negotiating methods do not yield impressive results any more in an organization of $150+$ members $^{41}$. In addition, a better anchoring of the freedom of transaction in domestic law should be considered (e.g. through attribution of direct effect to key WTO or FTA rules). Similarly, granting private parties the right to invoke the dispute settlement mechanism under the WTO and FTAs (similar to investor-state disputes under the ICSID ${ }^{42}$ convention) could provide an additional instrument to enforce agreed-upon principles. Such measures, which may seem utopian from today's perspective, have long been the subject of academic and policy-oriented debates. They may each have specific disadvantages, but should nevertheless be brought forward once again ${ }^{43}$.

\subsection{Investment policy: Monitoring and enforcement}

Monitoring: For the same reasons pointed out above (see Section 7.1. on trade policy), continued monitoring of investment measures through the OECD, UNCTAD, other international institutions and private initiatives such as GTA should continue.

Enforcement: Countries and investors should make use, to the maximum extent possible, of the dispute settlement and enforcement mechanisms laid down in international investment instruments against violations of agreed-upon investment disciplines. Such action raises the cost of protectionist measures (including reputation costs) and therefore deters potential violators.

${ }^{41}$ Proposals for reform have been made, inter alia, in Consultative BoARd (2004) and T. Cottier - S. Takenoshita, The Balance of Power in WTO Decision-Making - Towards Weighted Voting in Legislative Response, in «Aussenwirtschaft», 59 (2003), 2, pp. 171-214. ${ }^{42}$ International Centre for Settlement of Investment Disputes.

43 See, for instance, S. Charnovitz, The WTO and the Rights of the Individual, «Intereconomics - Review of European Economic Policy» 36 (2001), 2, pp. 98-108; P.C. MaVRoIdis ET AL., Is the WTO Dispute Settlement Mechanism Responsive to the Needs of the Traders? Would a System of Direct Action by Private Parties Yield Better Results? Panel Discussion at the 6th Geneva Global Arbitration Forum, «Journal of World Trade» 32 (1998), 2, pp. 147-165 and G.T. Schleyer Power to the People - Allowing Private Parties to Raise Claims Before the WTO Dispute Resolution System, «Fordham Law Review», 65 (1997), pp. 2275ff. on elements of this discussion. 
On-going negotiations on investment rules: With no major multilateral investment initiative in sight, countries mostly rely on a variety of instruments for the international regulation of cross-border investment, i.e. Bilateral Investment Treaties (BIT), Double Taxation Treaties (DTT; on tax matters), investment provisions in regional trade agreements, the TRIMS $^{44}$ in the WTO, and existing OECD instruments. In the absence of a broad-based multilateral agreement to protect investments, countries should continue to actively use and further develop such treaties with a view to providing a safety net and enhanced legal security for international investment. Such on-going negotiations also tend to counteract protectionist trends and help to lock-in past achievements.

Long-term options: Previous negotiations on a Multilateral Agreement on Investment (MAI) in the OECD between 1995 and 1998 have failed and efforts to integrate investment provisions into the WTO have met a cool response so far, particularly from developing countries. Nevertheless, seeking an agreement on a basic set of globally applicable rules for FDI might be worth a second attempt. The world has changed over the last 12 years, as emerging and developing countries have themselves become major home countries of foreign direct investment (e.g. South-South investment, South-North investment, SWFs).

\subsection{Fiscal policy: Making budget consolidation the top priority}

Communication of exit strategies: In order to restore fiscal discipline, prevent public finances from a continued degradation, and safeguard confidence in governments, the trend towards ever increasing public expenditure needs to be broken. This can best be achieved through timely, credible, and scheduled proposals by governments on how they plan to cut expenditures. The IMF ${ }^{45}$ recommends that fiscal stimulus packages should not have permanent effects on deficits; that frameworks with clearly defined policies and appropriate institutional arrangements should provide a commitment to fiscal correction.

Timely withdrawal of the government as entrepreneur: Government involvement in the management of otherwise privately run businesses (through guarantees, credits or outright ownership) should end at the earliest convenience, and before vested interests emerge that seek to perpetuate the

\footnotetext{
${ }^{44}$ Agreement on Trade-Related Investment Measures.

45 See International Monetary Fund (IMF) (ed.), Fiscal Implications of the Global Economic and Financial Crisis, IMF Staff Position Note, Doc. SPN/09/13, IMF, Washington, D.C., 9 June 2009. Available at http://www.imf.org/external/pubs/ ft/spn/2009/spn0913.pdf, p. 3 .
} 
control of government over specific firms or sectors. With regard to aid to the financial sector, sunset clauses on deposit insurance or bond guarantees, as well as punitive conditions of government capital injections (e.g. limitations on pay and bonuses) can contribute to a timely exit.

Making use of international instruments to contain fiscal activism: Although fiscal policy is largely a matter of domestic law and policy, there are some international instruments that can be used in order to contain the trend of governments to expand. For example, rules in the WTO and/or in the EU limit the scope of governments in granting subsidies. Another example is the Stability and Growth Pact in the EU which foresees warnings and sanctions against members without fiscal discipline. The partially poor application and enforcement of these rules in the past should not serve as a pretext of not applying them more strictly in the future.

Long-term measure: Stabilising public finances, revisiting the role of the state and implementing budget rules: In light of the magnitude of the debt/deficit problem, a radical departure from the general trend of the last four decades is required and the role of the state must be revisited more generally. Since 1970, the share of government disbursements as a percentage of GDP has continuously risen, as illustrated in Graph 18. For the OECD countries surveyed, this share ranges today between $31.3 \%$ in Korea and $56.0 \%$ in Sweden. Since 1970, the increase of this share has been 13.6 percentage points on average, ranging between a minimum of 9.2 percentage points in the United States and a maximum of 23.9 percentage points in the case of Spain, where the share of government disbursement in GDP has practically doubled in 40 years. This trend needs to be stopped, if any room for private economic initiative is to be left. As a key instrument of implementation, the introduction of budget rules (e.g. the Swiss debt brake) should be considered ${ }^{46}$. In states with decentralised governments (federations), reforming the fiscal relationship between the federal and the sub-federal level with a view to a clearer assignment of fiscal responsibilities, may contribute to successful fiscal adjustment ${ }^{47}$. Structural reforms should be implemented to enhance growth, and countries facing demographic pressures should embrace health and pension reforms.

\footnotetext{
${ }^{46}$ On the effectiveness of budget rules in general, see J.M. Poterba (1997): Do Budget Rules Work?, NBER Working Paper 5550, October 1997. Available at http://papers. nber.org/papers/w5550.pdf.

${ }^{47}$ See C.A. Schaltegger - L.P. Feld, Are fiscal adjustments less successful in decentralized governments? «European Journal of Political Economy», 25, 1, March 2009, pp. 115-123 (http://dx.doi.org/10.1016/j.ejpoleco.2008.08.002) with further references.
} 
Such reforms should be undertaken rather sooner than later, given the inherent delays in fiscal stabilisation processes ${ }^{48}$.

Figure 18 - Total disbursements, general government, as a percentage of GDP: Situation in 2010 and Change between 1970 and 2010

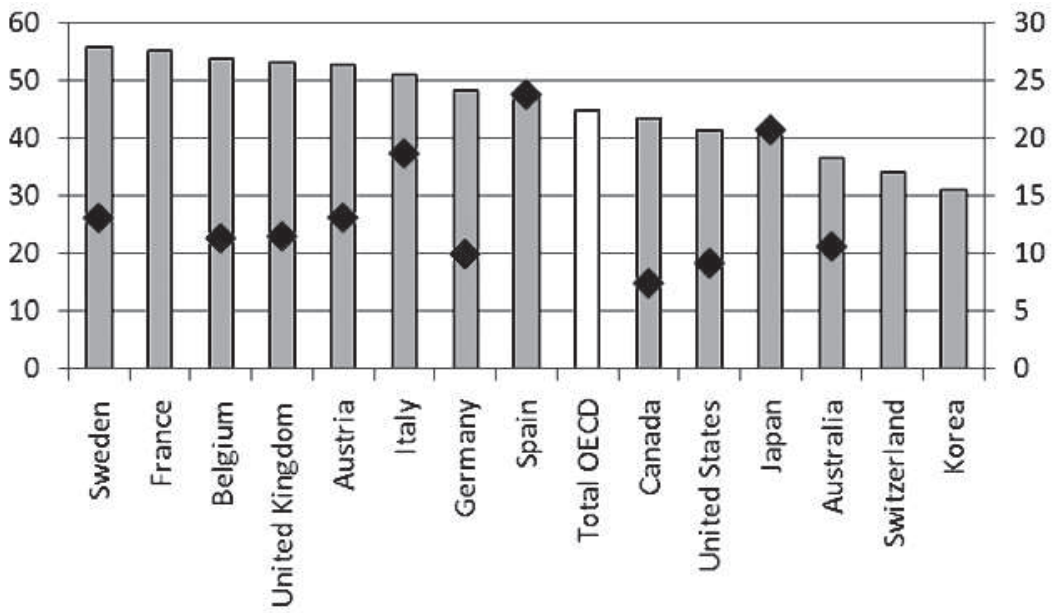

Total disbursement, general government, in \% of GDP (2010), left axis.

- Increase 1970 - 2010 in percentage points (right axis); where data is available.

Graph: Thomas A. Zimmermann; Data Source: OECD/OECD Economic Outlook Database, No. 86, Annual Data; vol. 2009/Issue No. 3 as per 4 January 2009; Source OECD: http://titania.sourceoecd.org/database/oecdeconomic outlook

Tax reforms should be considered but not with the primary aim of revenue increases: In the light of the growth of the state, fiscal consolidation should normally be achieved through lower expenditure and not through higher taxes. This recommendation is in line with evidence from research, suggesting that fiscal consolidations relying on spending cuts tend to be expansionary whereas consolidations relying on tax increases

\footnotetext{
48 See A. Alesina - A. Drazen, Why Are Stabilizations Delayed?, «American Economic Review», 18, 5 (December 1991), pp. 1170-1188, JSTOR, http://www.jstor.org/ stable/2006912? ? origin=JSTOR-pdf, with further references. On recent research on fiscal adjustments in general, see also S. Guichard ET AL., What Promotes Fiscal Consolidation - OECD Country Experiences, OECD Economics Department Working Papers, 553, OECD, Paris 2007. Available at http://dx.doi.org/10.1787/180833424370.
} 
tend to be contractionary ${ }^{49}$. In exceptional cases only, where such an approach would not be sufficient to restore the creditworthiness of a public entity, increased taxation could provide some temporary relief as ultima ratio. However, if taxes need to rise, the problem of the efficiency costs from increased taxation should be taken into account. The vast body of literature on optimal taxation can give some guidance on the criteria for modern tax systems and tax reform ${ }^{50}$. In the context of tax reform, policymakers could also address the debt-bias inherent in some tax systems. This includes corporate-level taxes that favour debt finance (including in the financial sector) and continued favourable treatment of housing (e.g. the tax deductibility of mortgage payments). This debt bias or, more generally, the lack of neutrality in the tax treatment of different financial arrangements, constitutes an intervention which creates macro-relevant distortions by fostering excessive leveraging in entire economies. These distortions should be removed ${ }^{51}$.

\subsection{Monetary policy: A timely exit and a revisited monetary policy target}

Timely monetary tightening: After some countries have already started monetary tightening (e.g. Israel, Australia and Norway), monetary authorities in other countries will have to think about a timely departure from the current lax monetary policies, too, if they wish to maintain their credibility and public confidence in central banks. This will not be an easy task, because higher interest rates and the unwinding of

${ }^{49}$ For recent research, see A. Alesina - S. Ardagna: Large Changes in Fiscal Policy - Taxes Versus Spending, NBER Working Paper 15438, issued in October 2009, revised version of 12 January 2010 (http://www.nber.org/papers/w15438), as well as C.D. Romer - D.H. Romer, The Macroeconomic Effect of Tax Changes - Estimates Based on a New Measure of Fiscal Shocks, NBER Working Paper W13264, July 2007 (http://www.nber.org/papers/w13264); the latter found that an exogenous tax increase of one percent of GDP lowers real GDP by roughly three percent (p. 42). See also A. Alesina - R. Perotti - J. Tavares, The Political Economy of Fiscal Adjustments, «Brooking Papers on Economic Activity», 1 (1998), pp. 197-266 (JSTOR, http:// www.jstor.org/stable/2534672? ?origin=JSTOR-pdf); A. Alesina - S. Ardagna, Tales of Fiscal Adjustment, «Economic Policy», 13 (1998), 27, pp. 489-545. Available at JSTOR, http://www.jstor.org/stable/1344762?origin=JSTOR-pdf.

${ }^{50}$ See, for instance, H.S. Rosen - T. GAYer, Public Finance, $8^{\text {th }}$ edition, Mc Graw Hill, Boston,MA, 2008, Part IV.

${ }^{51}$ See International Monetary Rund (IMF) (ed.), Debt Bias and Other Distortions Crisis-Related Issues in Tax Policy, IMF, Washington D.C., 12 June 2009. Available at http://www.imf.org/external/np/pp/eng/2009/061209.pdf, Chapters II and III. 
quantitative easing will raise borrowing costs and weigh on bond prices (pushing up yields), thus making investments and government debt service more costly. The alternative, though, is barely more attractive: Where excess liquidity is not withdrawn in a timely manner, it will flow into real assets such as commodities and will translate into higher inflation expectations; de-anchored inflation expectations would also raise borrowing costs through inflation premia and deter investment in general. Politically, monetary tightening will therefore require difficult choices, and timing will be a challenge. Technically, this issue appears to be less difficult as central banks can have recourse to a variety of instruments, mirroring the options they have used in the process of monetary easing: increasing interest rates, selling assets (including under repurchase agreements), modifying reserve requirements and interest rates on reserves, non-renewal of refinancing operations, terminating or adjusting funding facilities, normalising collateral rules, eliminating forex swap lines etc. Further measures could be the issuance of central banks' own debt in order to bind liquidity ${ }^{52}$.

Long-term measures: revisiting the monetary policy target: Central banks have largely focused on consumer price levels as their monetary target, neglecting asset prices and emerging bubbles. In the light of the enormous economic and social costs of the financial crisis which has resulted, at least partly, from too lax monetary policies and the bursting of the subsequent U.S. housing bubble, central banks may want to include the development of asset prices in their monetary policy assessments as well. Research undertaken suggests that there is scope for central banks to increasingly 'lean against the wind' of emerging asset price bubbles, as the latter are usually related to a build-up of leverage in the economy, as reflected by money and credit growth ${ }^{53}$.

Freeing exchange rates: There is no consensus in economic literature on whether floating or fixed exchange rates yield better results in the long run. The author of this paper subscribes to the view that freely floating exchange rates constitute necessary valves in the global economy and that the crisis has even increased their importance in the light of the large differences in macro-economic conditions between single currency areas (i.e. regarding economic growth rates and growth potential,

\footnotetext{
${ }^{52}$ See also BIS, $79^{\text {th }}$ Annual report, p. 123f.; IMF, Global Financial Stability report 2009, Chapter 3, pp. 18ff.

53 For an introduction into the discussion and further references, see L. Papademos, Monetary Policy and the 'Great Crisis' - Lessons and Challenges, Speech at the $37^{\text {th }}$ Economics Conference Beyond the Crisis - Economic Policy in a New Macroeconomic Environment, Vienna 14 May 2009, Available at http://www.ecb. int/press/key/date/2009/html/sp090514.en.html, part IV.
} 
budget deficits and debt levels, inflation preferences, trade structures etc.). We therefore view exchange rate interventions and currency pegs critically - in particular if countries with high current account surpluses like China keep their currencies at low levels, thus perpetuating international imbalances and creating protectionist pressures in importing countries. Letting major currencies float freely is a market-oriented approach and can help the adjustment process. Along the way, more floating currencies would also expand the spectrum of available reserve currencies, thus reducing pressure towards the use of the US Dollar as a reserve asset or towards the enhanced use of the IMF Special Drawing Right (SDR), as has been proposed. Other measures eyeing the exchange rate (such as the Brazilian tax on certain foreign investment or the Taiwanese ban for foreigners to invest in Taiwanese time deposits) should be phased-out, too.

\subsection{Other policy options}

The policy options discussed in Sections 7.1 through 7.4 address the same areas in which interventionism has taken place since the outbreak of the 2007-2009 financial crisis. In addition, there are a few further areas in which the crisis has either shown, or confirmed, the need for action.

Improving banking and bankruptcy regulation: One major area in which improved regulation is required, is the financial sector. As the BANK FOR International SetTlements (BIS) holds in its annual report 2009, banks «[...] must adjust by becoming smaller, simpler, and safer». Often, however, the emergency action by governments has led to the opposite, adding to systemic risk ${ }^{54}$. Against this background, improved banking regulation is a must with a view to prevent future crises and their huge economic and social costs. Options include simpler measures of lever-

${ }^{54}$ See BIS, $79^{\text {th }}$ Annual Report, p. 119. With regard to the rescue packages, the BIS holds that «[...] even where they have been essential, the government rescue packages implemented so far appear to be hindering rather than aiding this needed adjustment. By helping banks obtain debt financing and capital, rescue packages allow managers to avoid the hard choices needed to reduce both the size of their balance sheets (lowering leverage) and the amount of risk that they take (shifting the composition of the assets they hold). And by aiding the sale of distressed banks to other banks, as has been typical of many past crisis responses, government actions are creating financial institutions so big and complex that even their own management may not understand their risk exposures. Despite the nearly universal concern over the mere existence of institutions that are too big to fail, short-run government actions are increasing financial sector concentration and adding to systemic risk». 
age, higher capital requirements, and better risk assessment. In addition, bankruptcy rules need to be reviewed and, if necessary, re-designed with a view to preventing unnecessary damage from the failure of systemically relevant financial sector firms. Moreover, the distorting effect of the implicit state guarantee on financial institutions with systemic relevance (and the moral hazard that emerges in such situations) must be addressed. Or as the BIS (2009, p. 120) puts it: «[...] a financial firm that is too big or too interconnected to fail must be too big to exist».

Maintaining or restoring labour market and wage flexibility: An area, which at first sight has no direct relationship to the crisis and to the policy interventions which we have discussed, is the regulation of labour markets. However, the links are stronger than one might expect: Although the reasons for the stickiness of wages are subject to controversial debate in academic and policy-oriented literature, institutional rules and the flexibility of the labour market appear to play a crucial role. A highly regulated labour market with (high) minimum wages, compulsory industry-wide collective agreements, and high dismissal protection can react less flexibly to a fall in demand. As a consequence, the burden shifts towards trade protectionism and fiscal as well as monetary expansion. An economy with a labour market that is capable of adjusting to economic shocks and reduced demand without creating mass unemployment is less dependent on such interventions. In order to garner sufficient political support, liberal labour markets need to be bolstered by a reliable social security system. The latter, in turn, should be able to adjust to changes in the overall economic environment and it should not provide adverse incentives.

Ensuring sustainability in the use of the environment and of natural resources: An apparently unrelated issue is the question of the right governance of the environment and of resources as key production factors in the economy. However, there is a strong link since financial and economic stability require that the outstanding claims and obligations (e.g. money, bonds, other financial assets) be covered by production capacities in the real economy. The latter, in turn, require a safe supply of raw materials (e.g. metals, energy) and an ecological environment allowing for production (e.g fertile soil, clean water and air, and benign climatic conditions) as essential production factors. As these production factors often have the character of public goods, they tend to be overused or squandered in the absence of adequately defined property rights and regulations for their use. The rapid industrialisation of emerging markets has put additional strain on the world's resources, as has also become manifest in China's hunt for raw materials around the globe. 
By contrast to the interventionist approach to trade, fiscal and monetary policies, governments are only reluctantly addressing the sustainability issue, although the definition and the protection of property rights are a government's core business. The unsuccessful Copenhagen conference on climate change in late 2009 is an example in case of the continued tragedy of the global commons. Uncontrolled emissions of carbon dioxide and other greenhouse gases into the atmosphere, the contamination of oceans, other waters, and the air, as well as the loss of biodiversity create enormous costs and liabilities towards future generations which are nowhere accounted for and which are not being internalised in production costs. The same holds for the ease and the speed at which non-renewable resources - minerals, metals, and fossile fuels - are being extracted, consumed, and depleted. This speed stands in stark contrast to the arguably (lower) technological pace by which these resources can be substituted. The management of natural resources often occurs with a view to short-term profits, sometimes by hardly legitimate elites in poor countries and with little benefit to the local populations. The currently poor resource and environment policies therefore act as huge subsidies for certain economic activities and thus create considerable distortions in consumption, production and factor allocation. These are further exacerbated by the fiscal and monetary stimulus measures.

Reforms that would seriously address the sustainability issue are a political hard sell in short-sighted electoral cycles since they would create adjustment costs and weigh on the comfortable life styles in present-day industrialised societies. However, such reforms will ultimately be necessary if the world economy is to be brought on a sustainable, stability-oriented path.

\section{Conclusions}

This paper has reviewed the economic interventions by governments and central banks in response to the 2008-2009 financial and economic crisis.

In the area of trade policy, we have found that protectionism has increased substantially, with governments targeting in particular the products of declining industries and financial services. Although trade-restricting measures dominate the policy agenda, spiralling protectionism as in the 1930s has so far been avoided. 
In investment policy, the crisis has not led to a general increase of protectionist pressures for the time being. The outbreak of the financial crisis and the subsequent need to attract FDI inflows for the recapitalization of distressed financial institutions have even led to a softening of the stance towards SWFs in host countries. Nevertheless, the long-term trend towards liberalisation has recently been complemented by a trend towards more regulation - globally, and particularly in Latin America.

The main areas of economic interventionism, however, have been fiscal policy and monetary policy. On the fiscal side, important stimulus programs and emergency actions to stabilise the financial system have been implemented, involving governments in the credit business and in the management or ownership of firms, thus creating potential for state failures, moral hazard, political mismanagement, the emergence of vested interests and protectionist actions. At the macroeconomic level, these measures are associated with enormous costs to public finances and sometimes with the transfer of risky assets from the private to the public hand.

Monetary policy has been the other key element in economic interventionism. Central Banks have made full use of their arsenal of policy instruments: massive interest rate cuts, quantitative easing, and various other measures (including interventions on foreign exchange markets).

Given their cumulative size, these interventions hold a substantial potential for distortions and protectionism. They also raise important questions about negative side effects, including the erosion of government finances and the threat of future inflation. These concerns can be addressed, but they require constant monitoring of the affected policy areas and decisive action towards achieving a timely exit. 